\title{
EVROPSKÁ OBRANNÁ AGENTURA V ŠESTI LETECH
}

\section{THE EUROPEAN DEFENCE AGENCY AT SIX}

\author{
Vilém KOLÍN $N^{*}$
}

\begin{abstract}
Abstrakt
V roce 2010 uplyne šest let od založení Evropské obranné agentury (EDA), jejimž posláním je zlepšovat obranné schopnosti členských státu Evropské unie (EU) v oblasti řešení krizí pro plnění úkolů vyplývajících ze Společné bezpečnostní a obranné politiky (CSDP). Článek popisuje Strategický rámec EDA obsahující čtyři základní Strategické dokumenty korespondujici s úkoly EDA v oblasti rozvoje obranných schopností, podpory obranného výzkumu a technologií, podpory spolupráce ve vyzbrojování a tvorby Evropského trhu s obranným materiálem (EDEM) za současného posilování Evropské obranné technologické a průmyslové základny (EDTIB). Na pozadí tohoto Strategického rámce článek mapuje nejdưležitější současné projekty EDA a nastiňuje hlavní výzvy, které pred EDA v nebližši době stojí.
\end{abstract}

\begin{abstract}
In 2010, it will be six years since the establishment of the European Defence Agency (EDA), which seeks to improve defence capabilities of the Member States of the European Union (EU) in crisis management to sustain Common Security and Defence Policy (CSDP). The article describes the EDA Strategic Framework, consisting of four basic strategic documents that correspond with the EDA main tasks in the area of defence capabilities development, research and technology co-operation, armaments co-operation, and the creation of the European Defence Equipment Market (EDEM), while strengthening the European Defence Technological and Industrial Base (EDTIB). Against the background of the EDA Strategic Framework, the article maps the current major EDA projects and identifies the main challenges the EDA will face in the near future.
\end{abstract}

\section{Klíčová slova}

Společná bezpečnostní a obranná politika, Evropská obranná agentura, Evropská obranná technologická a průmyslová základna, Evropský obranný trh, Obranné schopnosti, Vyzbrojování, Výzkum a technologie.

\section{Keywords}

Armaments, European Defence Agency, European Defence Market, European Defence Technological and Industrial Base, Common Security and Defence Policy, Defence Capabilities, Research and Technology.

$$
* * *
$$

\section{ÚVOD - OD TEORIE K PRAXI}

V letošním roce, přesně dne 12. července 2010, uplyne šest let od rozhodnutí Evropské rady o založení Evropské obranné agentury (European Defence Agency - EDA), jejímž posláním je zlepšovat obranné schopnosti členských států ${ }^{1}$ Evropské unie (EU) v oblasti řešení krizí pro plnění úkolů vyplývajících ze Společné bezpečnostní a obranné politiky (Common Security and Defence Policy - CSDP). ${ }^{2}$ Když jsem v prosinci 2007 na stránkách Obrany a strategie poprvé popisoval hlavní aktivity EDA, měla Agentura za sebou relativně krátkou dobu své existence. ${ }^{3}$ Pro toto

\footnotetext{
*E-mail: kolinv@army.cz.
} 
období bylo charakteristické zahájení práce na prvních strategiích, politikách a projektech, které se postupně rozbíhaly v návaznosti na dokončení výstavby organizačně-administrativních struktur v únoru 2005 pod vedením prvního výkonného ředitele EDA Angličana Nicka Witneyeho. S nástupem druhého a dosavadního výkonného ředitele EDA Němce Alexandra Weise v říjnu 2007 se Agentura zaměřila na dokončení hlavních strategií a především pak na realizaci společných projektů k podpoře obranných schopností členských států EU. Necelých šest let od rozhodnutí o založení EDA je možné stále více charakterizovat činnost Agentury slovy jejího současného výkonného ředitele, který její náplň před časem výstižně popsal třemi slovy: „projekty, projekty, projekty“. ${ }^{4}$ Jaké jsou hlavní současné projekty EDA? V jakém strategickém rámci se tyto projekty realizují? V jaké situaci se EDA nachází a jaké výzvy před ní stojí? Na tyto a související otázky se pokusí odpovědět následující článek.

\section{STRATEGICKÝ RÁMEC EDA A HLAVNí PROJEKTY}

Třebaže hlavní pozornost Agentury se dnes podle slov jejího výkonného ředitele soustřed'uje na projekty, jejich realizace je součástí Strategického rámce EDA, bez něhož by tyto projekty byly jen pouhou improvizací. Samotný Strategický rámec EDA se skládá ze čtyř dokumentů přijatých Ř́dícím výborem EDA v letech 2007-2008: Plánu rozvoje schopností (Capability Development Plan - CDP), Strategie evropského obranného výzkumu a technologií (European Defence Research and Technology - EDRT), Strategie evropské spolupráce ve vyzbrojování (European Armaments Co-operation Strategy - EACS) a Strategie evropské obranné technologické a průmyslové základny (European Defence Technological and Industrial Base - EDTIB). Tyto dokumenty poskytují základní návod, s jehož pomocí se EDA snaží naplnit své poslání v podobě zlepšování obranných schopností členských států EU v oblasti řešení krizí pro plnění úkolů vyplývajících z CSDP. Současně také operacionalizují čtyři hlavní funkce, které Agentura při naplňování svého poslání daného Společnou akcí (Joint Action - JA) Rady - zakládajícím dokumentem EDA, vykonává: podporuje rozvoj obranných schopností (Capabilities), podporuje obranný výzkum a technologie (Research and Technology - R\&T), podporuje spolupráci ve vyzbrojování (Armaments) a tvorbu Evropského trhu s obranným materiálem (European Defence Equipment Market - EDEM) za současného posilování Evropské obranné technologické a průmyslové základny (EDTIB). ${ }^{5}$

Jak vyplývá z funkcí, jež EDA vykonává, rozvoj obranných schopností členských států EU je komplexním procesem, který zahrnuje nejen propojení obranného plánování, výzkumu a vyzbrojování, ale i průmyslu. Tento tzv. integrovaný přístup (Integrated Approach) je charakteristický pro Strategický rámec EDA i pro všechny projekty, které se v tomto rámci odehrávají. Strategický rámec EDA v čele se CDP konkretizuje cílový stav (ve smyslu určení, jaké obranné schopnosti, jaký výzkum a technologie, jaké projekty vyzbrojování a jaké průmyslové schopnosti je třeba rozvíjet a posilovat) a způsob, jakým má tohoto stavu být dosaženo (pomocí definovaných priorit, metodologií a procesů). Prostředkem $\mathrm{k}$ dosažení cílového stavu a zároveň výstupem implementace Strategického rámce EDA jsou pak konkrétní projekty zaměřené na zlepšení obranných schopností členských států EU voblasti řešení krizí pro plnění úkolů vyplývajících z CSDP.

Ačkoli dokumenty tvořící Strategický rámec EDA mají jasný účel, je třeba podotknout, že jsou relativně nestejnorodé, jejich text není vždy srozumitelný a jejich obsah není často dostatečně vzájemně provázán. Tato určitá nekonzistentnost a nekoherentnost je dána jednak odlišným datem vzniku těchto dokumentů, jednak snahou EDA soustředit se primárně na realizaci projektů, politik a činností, které často jako v případě prvotních vlajkových projektů (Flagship Projects) výkonného ředitele Nicka Witneyeho krystalizovaly dříve než snahy o vytvoření specifického teoretického rámce pro jejich zařazení. ${ }^{6}$ Navzdory tomu je možné konstatovat, že všechny čtyři dokumenty Strategického rámce EDA působí navenek jako celek a poskytují Agentuře i jejím členským státům základní referenční rámec pro zlepšení obranných schopností EU a vzájemnou interakci. 


\section{Schéma: Strategický rámec EDA ${ }^{7}$}

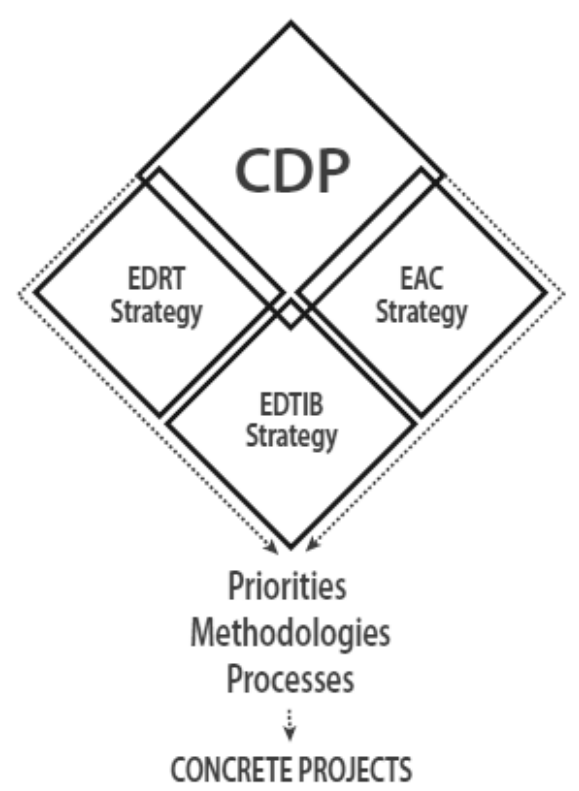

Zdroj: WEIS, s. 2 (přetištěno se souhlasem EDA).

\section{Plán rozvoje schopností}

Vzhledem k zaměření Agentury je hlavním dokumentem Strategického rámce EDA Plán rozvoje schopností. CDP navazuje na závěry Počáteční dlouhodobé vize požadavků na evropské obranné schopnosti a kapacity (LTV) přijaté Řídícím výborem na úrovni ministrů obrany v ř́inu $2006 .{ }^{8}$ Hlavním cílem CDP, který byl schválen o téměř dva roky později v červenci 2008 Řídícím výborem EDA na úrovni národních ředitelů pro schopnosti, je postavit rozvoj obranných schopností členských států EU na systematickém základě. ${ }^{9}$ Smyslem CDP je pomoci členským státům EDA rozvinout národní plány a programy v souladu s cíli a zdroji a sladit rozvoj obranných schopností v souhlase se společnými (evropskými) prioritami, což by mělo pomoci členským státům EDA redukovat předpokládaná operační, technická a finanční rizika. CDP je komplementárním dokumentem k Evropské bezpečnostní strategii (European Security Strategy ESS). ${ }^{10}$ Zatímco ESS mapuje prostředí, ve kterém se EU nachází, identifikuje potenciální hrozby a rizika a formuluje doporučení, CDP poskytuje návod na zlepšení obranných schopností členských států EU tak, aby bylo možné ESS v rámci CSDP operacionalizovat. ${ }^{11}$ Vedle návodu na rozvoj obranných schopností slouží CDP i jako prostředek pro identifikaci př́iležitostí pro spolupráci v oblasti rozvoje obranných schopností mezi členskými státy EDA.

Z věcného hlediska CDP identifikuje trendy v oblasti rozvoje schopností do roku 2025 a dále, které vyvolávají potřebu rozvoje profesní interoperability (koncepcí, doktrín, výcviku, koordinační architektury, zvýšení vzdělanosti vojenské i civilní složky operací a udržení morálky) a staví ji na stejnou úroveň jako potřebu rozvoje technické interoperability (pořízení nové výstroje a výzbroje). ${ }^{12}$ V závislosti na identifikovaných trendech v rozvoji obranných schopností, CDP generuje 12 prioritních oblastí (včetně zdůvodnění, shrnutí současné situace a navrhované cesty vpřed), které mají být v EDA za spolupráce s Vojenským štábem (EU Military Staff - EUMS) a Vojenským výborem (EU Military Committee - EUMC) dále rozpracovány na konkrétní projekty. Mezi tyto oblasti patři ochrana proti přenosným protivzdušným obranným systémům 
(Counter Man-portable Surface-to-air Missiles - C-MANPADs), operace zaměřené na počítačové sítě (Computer Network Operations), prostředky proti pobřežním nástražním minám, komplexní prrístup - vojenské implikace, kulturní a jazykový výcvik ve vojenském zpravodajství, zpravodajská, sledovací, naváděcí a průzkumná architektura (Intelligence, Surveillance, Target Acquisition and Reconnaissance - ISTAR), zdravotnická podpora, ochrana proti chemickým, biologickým a radionukleálním zbraním (Chemical, Biological, Radiological and Nuclear CBRN), logistická podpora třetích stran, ochrana proti improvizovaným výbušným zařízením (Counter Improvised Explosive Devices - C-IEDs), zvýšení dostupnosti vrtulníků a sítově podporovaná schopnost (Network Enabled Capability - NEC). ${ }^{13}$

CDP současně identifikuje klíčové potřeby rozvoje obranných schopností EU vyplývající z Linie B CDP, které zahrnují schopnost plánovat, připravit a provést operace s maximálním využitím znalostí, schopnost rozvinout společné plány a doktríny, schopnost nepřetržitého zpravodajství, schopnost vést komplexní a koordinované operace předpokládající strategickou a operační integraci vojenských, civilních, diplomatických, hospodářských a dalších komponent, schopnost zajistit svobodu manévru, schopnost rozvinout adaptivní společné sily, schopnost dosáhnout strategické a operační mobility a schopnost rozvinout lidský faktor. ${ }^{14}$

V neposlední řadě CDP identifikuje 19 možných příležitostí pro spolupráci mezi členskými státy EDA. Tyto prŕležitosti byly identifikovány na základě analýzy národních projektů uvedených v databázi Linie C CDP (nově nazývané kooperační databáze - Co-operative Database - CoDaBa) obsahujících stovky projektů, kdy EDA vyhledala shodné nebo podobné národní projekty členských států.

$\mathrm{K}$ identifikovaným oblastem patří: detekce biologických látek, bezpilotní letecké (bojové) prostředky (Unmanned Aerial Vehicles - UAVs a Unmanned Combat Aerial Vehicles - UCAVs), alternativy k pěchotním minám, C-IEDs, ochrana vojenských počítačových sítí, komunikační systémy, ochrana vojáka proti účinkům zbraní CBRN, likvidace zbraní CBRN, ochrana vozidel, identifikace, protivzdušná obrana, bezpilotní letecké prostředky - systém vyhnutí (Sense and Avoid), prostředky proti námořním minám, systém zásobování vodou v bojových podmínkách, vyhledávací a záchranné vrtulníky, nepřímá palba, přesná munice pro nepřímou palbu a kontrola leteckého provozu. ${ }^{15}$

\section{... a současné hlavní projekty EDA v oblasti rozvoje schopností}

Jedním z hlavních současných projekti̊ EDA voblasti rozvoje obranných schopností vycházejících ze CDP je výcvik osádek vrtulníkủ. Tato aktivita se soustředí na pomoc členským státům EDA v procesu př́ípravy osádek vrtulníků na dosažení operačních schopností a na nasazení v zahraničních operacích. Prostředkem k dosažení tohoto cíle je Vrtulníkový výcvikový program (Helicopter Training Programme - HTP), který byl schválen Ř́ícícím výborem EDA na úrovni ministrů obrany v listopadu 2009. ${ }^{16}$ Obsahem programu, jenž se naplno rozběhne v průběhu roku 2010, jsou dvě cvičení ročně, z nichž jedno je zaměřené na individuální výcvik a výcvik v přírodních podmínkách a druhé na interoperabilitu a taktický výcvik. Průběh cvičení bude následně analyzován a výstupy této analýzy distribuovány prostřednictvím výročního taktického sympozia, které na jejich základě navrhne doporučení pro následující cvičení. ${ }^{17}$ Co se týče podílu ČR na této aktivitě, ČR byla jedním z prvních členských států EDA (a z hlediska studie EDA k této problematice z roku 2009 i prŕípadovou zemí), jejíž osádky vrtulníků se v rámci př́ípravné fáze programu zúčastnily taktického výcviku pro nasazení v operaci ISAF (International Security Assistance Force) v Afghánistánu. Očekává se, že se ČR stane i jedním ze šesti přispívajících států EDA (CZ, HU, LU, SE, SI a UK) projektu kategorie B s názvem Syntetický vrtulníkový taktický výcvikový kurz (Interim Synthetic Helicopter Training Course - ISHTC), který bude řešit výcvik osádek vrtulníků s využitím simulačních technologií. ${ }^{18}$

Mezi další významné projekty EDA v oblasti rozvoje obranných schopností patři projekt Satelitního sledování povrchu země z vesmíru (Multinational Space-based Imaging System for 
Surveillance, Reconnaissance and Observation - MUSIS), kdy šest zúčastněných států EDA (BE, DE, EL, ES, FR a IT) sdružených v rámci projektu kategorie B plánuje vytvoření mnohonárodního, satelitního, přehledového sledovacího systému k pozorování, sledování a průzkumu v rámci operací CSDP po roce 2017 jako náhrady za stávající systémy HELIOS II, SAR-Lupe, COSMO-SkyMed a Pléiades. ${ }^{19} \mathrm{~V}$ oblasti využití vesmíru se je třeba zmínit i o projektu pěti států EDA (FR, IT, NL, PL a UK) k vytvoření akviziční skupiny v rámci projektu kategorie B k nákupu služeb satelitní komunikace pro evropské účely (European Satellite Communication Procurement Cell - ESCPC). Tento projekt má za cíl poskytnout na základě komerčního řešení bezdrátové satelitní spojení mezi velitelstvím a místem nasazení, př́ípadně dalšími strukturami a jednotkami $\mathrm{v}$ operacích. EDA pak bude vystupovat v roli kontraktační autority pro členské státy, které mají o nákup těchto služeb zájem. ${ }^{20}$ Neméně důležitým projektem z hlediska rozvoje obranných schopností je projekt kategorie B k Systému vyhnutí pro UAVs (Mid-air Collision Avoidance System - MIDCAS), kterého se účastní pět států (DE, ES, FR, IT a SE) s cílem do roku 2012 vyvinout technologický demonstrátor jako předpoklad pro zařazení UAVs do nesegregovaného vzdušného prostoru do roku 2015, tzn. k zajištění schopnosti UAVs létat ve stejném vzdušném prostoru současně s pilotovanými leteckými prostředky. ${ }^{21}$ Mimo vesmírný a vzdušný segment se EDA intenzivně věnuje i námořní oblasti, kde probíhá projekt kategorie $\mathrm{B}$ s názvem Budoucí bezpilotní letecké systémy (Future Unmanned Aerial System - FUAS), kterého se účastní sedm členských států EDA (DE, ES, FI, FR, PL, PO a SE), a projekt kategorie B s názvem Opatření proti námořním minám (Maritime Mine Counter Measures - MMCM), na kterém participuje 11 členských států EDA (BE, DE, EE, ES, FI, FR, NL, PL, PO, RO a SE) a Norsko. Cílem obou projektů je vytvoření technického řešení pro relevantní systémy nové generace využitelné $\mathrm{v}$ rozmezí let 2022-2025. ${ }^{22}$ V oblasti komunikačních systémů je pak možné uvést projekt softwarového rádia (Software Defined Radio - SDR), kterého se v rámci kategorie B projektu účastní šest států EDA (ES, FI, FR, IT, PL a SE) a jehož cílem je do roku 2013 vytvořit podmínky pro vývoj a výrobu softwarového rádia v EU. ${ }^{23}$

Další z významných aktivit v oblasti rozvoje obranných schopností, na které se aktivně podílí i ČR, je vytvoření evropské letecké transportní flotily (European Air Transport Fleet - EATF). Smyslem iniciativy EATF je zvýšit efektivitu ve využívání vojenských leteckých prostředků členských států EDA. Iniciativa EATF vytváří rámec pro řadu souvisejících aktivit majících za cíl optimalizaci spolupráce a koordinace ve využití letecké přepravy s cílem vytvořit sít' evropských poskytovatelů vojenské letecké techniky bez ohledu na její typ a původ. Zapojení členských států EDA do iniciativy EATF je modulární a mělo by mít čtyři různé formy: nabídka volných kapacit vojenských dopravních letadel, nákup letových hodin, nabídka/výměna letových hodin, nabídka/využití sdílených podpůrných funkcí. ${ }^{24}$ Mezníkem $\mathrm{k}$ implementaci iniciativy EATF bylo podepsání Deklarace zájmu (Letter of Intent - LoI) 14 členskými státy EDA (BE, CZ, DE, ES, FI, FR, GR, IT, LU, NL, PL, RO, SE a SK) na jednání Ř́íícího výboru EDA na úrovni ministrů obrany v listopadu 2009. ${ }^{25}$ Podpisem LoI se vytvořily podmínky pro podrobnější rozpracování konceptu EATF včetně mechanismu správy, rrízení, harmonizace pravidel, nařízení a dokumentů, které s ustavením mnohonárodní letecké transportní flotily souvisí.

Neméně významnou aktivitou EDA s přímým vlivem na zlepšení obranných schopností EU je činnost EDA v oblasti logistické podpory třetích stran (Third Party Logistic Support - TPLS). V dubnu 2009 Řídící výbor EDA na úrovni národních ředitelů pro vyzbrojování rozhodl o zřízení portálu TPLS, který má za cíl zlepšit a zjednodušit identifikaci komerčních logistických řešení při přípravě a plánování operací. ${ }^{26}$ Vytvoření portálu TPLS je prvním krokem ke zlepšení spolupráce mezi státy poptávajícími logistická řešení na straně jedné a průmyslovými subjekty nabízejícími logistické služby na straně druhé. Portál TPLS, který je spravován EDA, byl spuštěn 1. července $2009 .^{27}$

Mimo výše uvedené projekty a iniciativy Agentura rozvíjí celou škálu činností v oblasti rozvoje obranných schopností v návaznosti na CDP, které zahrnují mj. formulaci konceptu námořního sledování, NEC a vojáka 21. století, zpravodajského kurzu a kurzu C-IEDs, mapování 
situace okolo C-MANPADs, CBRN, problematiky lékařské podpory, neletálních zbraní (Non-lethal Wapons - NLW), komunikačních a informačních systémů a dalších oblastí souvisejících s rozvojem obranných schopností EU. Správa a rozvoj těchto a př́buzných aktivit je součástí každodenní činnosti ředitelství EDA pro schopnosti, které je na expertní úrovni provázáno s jednáními pracovních skupin zainteresovaných členských států v rámci šesti tematicky zaměřených Integrovaných rozvojových týmů (Integrated Development Teams - IDTs) a jim podřízených Projektových týmů (Project Teams - PTs). ${ }^{28}$

\section{Strategie Evropského obranného výzkumu a technologií}

V pořadí druhým dokumentem Strategického rámce EDA je Strategie Evropského obranného výzkumu a technologií, která byla schválena Ř́dícím výborem EDA na úrovni ministrů obrany v listopadu 2008. ${ }^{29}$ Přijetí Strategie EDRT bylo reakcí na skutečnost, že většina výdajů na R\&T, přibližně $82 \%$ v roce 2008, je realizována národně, což se vzhledem k množství a rozsahu

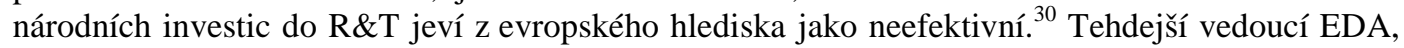
Generální tajemník Rady a vysoký představitel pro Společnou zahraniční a bezpečnostní politiku (Common Foreing and Security Policy - CFSP), Javier Solana proto na neformálním jednání ministrů obrany EU v Hampton Court v ř́ijnu 2005 vyzval členské státy, aby investovaly do R\&T více, lépe a více společně. ${ }^{31}$ Tato výzva byla podpořena jednáním Řídícího výboru EDA na úrovni ministrů obrany v listopadu 2007, který s cílem zvýšit společné výdaje na R\&T schválil společné srovnávací ukazatele (benchmarks), mj. i pro podíl R\&T na celkových národních výdajích na obranu ve výši $2 \%$ a společných výdajů R\&T v rámci EU na celkových obranných výdajích na R\&T ve výši $20 \% .^{32}$

Smyslem Strategie EDRT je poskytnout členským státům EDA, průmyslu a Agentuře samotné návod při investování do oblasti R\&T s cílem zajistit konvergenci těchto investic napříč členskými státy EDA a zvýšit tak koherenci v R\&T činnostech souvisejících s obranným plánováním, výzkumem a technologiemi, které je třeba vyvinout s ohledem na zlepšení obranných schopností EU. ${ }^{33}$ Vyšším cílem je pak zajistit technickou a technologickou převahu EU na bojišti a současně zvýšit návratnost R\&T investic v kontextu budování životaschopné, konkurenceschopné a agilní EDTIB, jejíž zdroje mají pomoci překlenout propast mezi obrannými schopnostmi EU a USA, vůči kterým se EU obecně ve svém snažení vymezuje.

Strategie EDRT jako dokument poskytuje základní rámec pro rozvoj obranného výzkumu a technologií. Integruje klíčové aktéry nabídky a poptávky (včetně států, průmyslu, výzkumných zařízení a univerzit) do soustředěného proudu, který jim má umožnit podílet se vývoji špičkových technologií. Tyto technologie jsou obsažené ve 22 obecně definovaných technologických oblastech, které Strategie EDRT označuje jako cíle (Ends). ${ }^{34}$ Definované technologické oblasti je podle Strategie EDRT třeba v EU zachovat a dále rozvíjet, nebot' bez nich, jak Strategie naznačuje, nebude možné dosáhnout obranných schopností EU nutných pro plnění úkolů vyplývajících z CSDP. ${ }^{35}$ Mezi tyto oblasti patří mj. energetické materiály a zdroje energie, fyzická ochrana, bezosádkové námořní a pozemní systémy, systémová integrace vojáka včetně prostředí NEC, technologie velení a řízení, letecké platformy včetně vrtulníkủ a UAVs, komunikační a informační technologie, senzory, elektronická zařízení, sledování prostředí, simulace a modelování. ${ }^{36}$

Prostředkem k naplnění cílů (Ends) Strategie EDRT jsou společné R\&T projekty využívající současného institucionálního rámce $\mathrm{EDA}$, tzn. projekty kategorie $\mathrm{A}, \mathrm{B}$, společné investiční programy nebo projekty financované z operačního rozpočtu EDA. Strategie EDRT také definuje doprovodné prostředky (Means), které představují cíle v podobě rámců, mechanismů, procesů a struktur, jež je třeba při realizaci společných R\&T projektů sledovat. Tyto doprovodné prostředky (Means) v podobě cílů Strategie EDRT rozděluje do tří skupin:

- Posilování integrace obranné technologické a průmyslové základny: prostředky v této oblasti zahrnují vytvoření strategického dialogu mezi výzkumnými zařízeními a průmyslem, zlepšení koordinace R\&T činností, rozš̌řrení dodavatelské základny a podpora 
vzorových R\&T sítí (R\&T Network of Excellence). Tyto prostředky usilují o zvýšení konkurenceschopnosti a zlepšení efektivity evropského obranného průmyslu s pomocí rozvoje výzkumné a technologické základny.

- Podpora technologického pokroku: prostředky v této oblasti zahrnují zlepšení sdílení R\&T výsledků s pomocí ustavení evropského sledovacího mechanismu propojujícího národní experty, zvýšení povědomí o využívání konkrétních technologií včetně civilních pro obranné účely a vypracování cestovních map (roadmaps) v oblasti R\&T. Tyto prostředky mají za cíl zajistit, aby EU byla oproti svým protivníkům vždy napřed ve využívání stávajících technologií a zároveň byla schopná identifikovat nové technologie, které by přispěly k naplňování cílů (Ends).

- Zvýšení efektivity R\&T spolupráce: prostředky v této oblasti zahrnují přijetí silnějších závazků k R\&T spolupráci, zlepšení efektivity řízení R\&T včetně financování, vytvoření stimulujícího prostředí pro R\&T spolupráci a urychlení aplikace nových technologií do národních programů. Tyto prostředky mají za cíl zrychlit a zefektivnit dosažení cílů (Ends), které by se mělo bezprostředně projevit ve zlepšení obranných schopností členských států EU. ${ }^{37}$

\section{... a současné hlavní projekty EDA v oblasti výzkumu a technologií}

Koordinace při využívání omezených národních zdrojů voblasti R\&T, snaha o jejich efektivnější vynakládání doprovázená úsilím o zvýšení potenciálu EU, získání vedení nebo alespoň nezaostávání ve vývoji a aplikaci klíčových technologií v globálním kontextu, které je na pozadí Strategie EDRT, vyžaduje realizaci společných R\&T projektů. Tyto projekty mají v EDA nejčastěji podobu projektů kategorie $\mathrm{B}$, tzn. projektů, které jsou iniciovány dvěma nebo více členskými státy zainteresovanými na řešení konkrétní problematiky v působnosti EDA. ${ }^{38} \mathrm{~V}$ rozmezí let 2007-2009 byly Řídícím výborem EDA schváleny projekty kategorie B v celkové hodnotě 278 mil. eur, přičemž hodnota kontraktů uzavřených v rámci těchto projektů dosáhla celkové částky 222 mil. eur. ${ }^{39}$ Součástí těchto projektů jsou i projekty kategorie B uvedené v diskusi o projektech v oblasti rozvoje obranných schopností, nebot' řada prioritních oblastí CDP má podstatnou R\&T dimenzi a mechanismus projektu kategorie B je aplikovatelný na všechny oblasti působnosti Agentury. Jen v roce 2009 bylo podepsáno 19 nových projektů v celkové hodnotě cca 131 mil. eur. ${ }^{40}$ Současně bylo ukončeno osm projektů v celkové výši cca 78,5 mil. eur. ${ }^{41}$

Vzhledem k omezeným výdajům na R\&T na národní úrovni a klesajícím výdajům na obranu jako celek, rostoucím nákladům na výzkum a vývoj nových technologií a $\mathrm{k}$ faktické nemožnosti saturovat vývoj a výzkum konkrétního zařízení výlučně $\mathrm{z}$ domácích zdrojů lze v obecné rovině konstatovat, že bez společných R\&T projektů nebude ve většině případů v budoucnu možné v EU zachovat a rozvinout technologické oblasti obsažené ve Strategii EDRT ani zásadně zlepšit obranné schopnosti členských států EU, které jsou na těchto technologiích závislé. Hlavním nástrojem EDA pro zlepšení obranných schopností jako celku jsou společné R\&T projekty ve formě Společných investiční programů (Joint Investment Programme - JIP) kategorie A, které jsou iniciovány ze strany EDA a předpokládají účast všech nebo alespoň většiny členských států EDA. V současnosti existují dva takové programy.

První JIP s názvem Ochrana vojsk (Force Protection - FP) byl schválen Řídícím výborem EDA na úrovni ministrů obrany v listopadu $2006 \mathrm{~s}$ cílem vyvinout technologie k ochraně vojsk členských států EU proti improvizovaným nástražným zařízením, odstřelovačům a dalším hrozbám. ${ }^{42}$ Program s rozpočtem cca 55 mil. eur zahrnuje 19 členských států EDA včetně ČR (AT, BE, CY, DE, EE, ES, FI, FR, GR, HU, IE, IT, NL, PL, PO, SE, SI a SK) a Norsko. ${ }^{43} \check{C ̆ R}_{\text {do }}$ 
Tabulka: Projekty kategorie B uzavřené v roce $2009^{44}$

\begin{tabular}{|c|c|c|c|c|c|}
\hline $\begin{array}{l}\text { Zkratka } \\
\text { projektu/ } \\
\text { CapTech }\end{array}$ & Název projektu & $\begin{array}{l}\begin{array}{l}\text { Účastnické } \\
\text { státy } \\
\text { Vedoucí stát }\end{array} \\
\end{array}$ & $\begin{array}{c}\text { Datum podpisu } \\
\text { Technické } \\
\text { dohody } \\
\text { (TA)/Programové } \\
\text { dohody (PA) }\end{array}$ & $\begin{array}{l}\text { Datum } \\
\text { podpisu } \\
\text { kontraktu }\end{array}$ & $\begin{array}{l}\text { Hodnota projektu } \\
\text { v tis. eur (včetně } \\
\text { DPH a } \\
\text { spolufinancování) }\end{array}$ \\
\hline $\begin{array}{c}\text { COMARMS } \\
\text { IAP2 }\end{array}$ & $\begin{array}{c}\text { EW Common } \\
\text { Modular } \\
\text { Architecture for } \\
\text { Mission } \\
\text { Simulation }\end{array}$ & $\underline{\text { SE}}, \mathrm{ES}$ & 02/02/09 & $\begin{array}{l}\text { Národní } \\
\text { kontrakty }\end{array}$ & 300 \\
\hline $\begin{array}{l}\text { HDR-RF } \\
\text { IAP4 }\end{array}$ & $\begin{array}{c}\text { High Data Rate } \\
\text { Technology for } \\
\text { HF } \\
\text { Communications }\end{array}$ & $\underline{\mathrm{DE}}, \mathrm{BE}, \mathrm{FR}$ & 26/02/09 & 02/04/09 & 5410 \\
\hline $\begin{array}{c}\text { SOCUMOD } \\
\text { ESM4 }\end{array}$ & $\begin{array}{c}\text { Social \& } \\
\text { Cultural } \\
\text { Modelling of } \\
\text { Headquarters } \\
\text { and Operations }\end{array}$ & $\frac{\text { SE, BE, DE, }}{\text { FR, NL }}$ & $31 / 03 / 09$ & $\begin{array}{c}\text { Bez } \\
\text { kontraktu - } \\
\text { Studie }\end{array}$ & 0 \\
\hline $\begin{array}{c}\text { IMA } \\
\text { GEM2 }\end{array}$ & $\begin{array}{c}\text { Insensitive } \\
\text { Munitions and } \\
\text { Ageing }\end{array}$ & $\begin{array}{l}\underline{\text { FR, CZ, FI, }} \\
\text { DE, NL, SE, } \\
\quad \text { UK }\end{array}$ & $31 / 03 / 09$ & $\begin{array}{l}\text { Národní } \\
\text { kontrakty }\end{array}$ & 4050 \\
\hline $\begin{array}{c}\text { SAM-UGV } \\
\text { GEM3 }\end{array}$ & $\begin{array}{c}\text { Semi- } \\
\text { Autonomous } \\
\text { Small Ground } \\
\text { Vehicle } \\
\text { System } \\
\text { Demonstrator }\end{array}$ & $\underline{\mathrm{DE}}, \mathrm{FR}$ & $21 / 04 / 09$ & $19 / 05 / 09$ & 4008 \\
\hline $\begin{array}{c}\text { QPP } \\
\text { ESM1 }\end{array}$ & $\begin{array}{l}\text { Quiescent Period } \\
\text { Prediction }\end{array}$ & $\begin{array}{l}\underline{\mathrm{ES}}, \mathrm{FI}, \mathrm{FR}, \\
\text { IT }\end{array}$ & $24 / 04 / 09$ & $\begin{array}{c}\text { Národní } \\
\text { kontrakty }\end{array}$ & 1534 \\
\hline $\begin{array}{c}\text { BaToLUS } \\
\text { GEM1 }\end{array}$ & $\begin{array}{l}\text { Battle Damage } \\
\text { Tolerance for } \\
\text { Lightweight } \\
\text { UAV Structures }\end{array}$ & $\underset{\text { DE, }}{\text { FR, SE, }}$ & $19 / 05 / 09$ & $26 / 10 / 09$ & 4495 \\
\hline $\begin{array}{l}\text { UGTV } \\
\text { GEM3 }\end{array}$ & $\begin{array}{c}\text { Unmanned } \\
\text { Ground Tactical } \\
\text { Vehicle }\end{array}$ & $\begin{array}{l}\text { IT, DE, EL, } \\
\text { FI, FR, PL, } \\
\text { PT }\end{array}$ & $26 / 05 / 09$ & 03/08/09 & 1227 \\
\hline $\begin{array}{c}\text { MIDCAS } \\
\text { ARM }\end{array}$ & $\begin{array}{l}\text { MidAir Collision } \\
\text { Avoidance } \\
\text { System }\end{array}$ & $\begin{array}{c}\text { SE, DE, ES, } \\
\text { FR, IT }\end{array}$ & $17 / 06 / 09$ & $17 / 06 / 09$ & 60359 \\
\hline $\begin{array}{l}\text { APSS } \\
\text { ARM }\end{array}$ & $\begin{array}{c}\text { Active } \\
\text { Protection } \\
\text { System Study }\end{array}$ & $\begin{array}{l}\mathrm{DE}, \mathrm{FI}, \mathrm{NL}, \\
\mathrm{PL}\end{array}$ & 19/06/09 & $\begin{array}{c}\text { Kontrakt } \\
\text { zatím } \\
\text { nepodepsán. }\end{array}$ & 800 \\
\hline $\begin{array}{c}\text { ECOCOAT } \\
\text { GEM1 }\end{array}$ & $\begin{array}{c}\text { Environmentally } \\
\text { Compliant } \\
\text { Coatings in } \\
\text { Aeronautics }\end{array}$ & $\begin{array}{l}\mathrm{FR}, \mathrm{DE}, \mathrm{IT}, \\
\mathrm{FI}\end{array}$ & $30 / 09 / 09$ & 09/12/09 & 3375 \\
\hline
\end{tabular}




\begin{tabular}{|c|c|c|c|c|c|}
\hline $\begin{array}{c}\text { CAPRICORN } \\
\text { ESM3 }\end{array}$ & $\begin{array}{l}\text { CIMIC and } \\
\text { Planning } \\
\text { Research in } \\
\text { Complex } \\
\text { Operational } \\
\text { Realistic } \\
\text { Network }\end{array}$ & $\underline{\text { IT }}, \mathrm{FR}$ & $13 / 11 / 09$ & $18 / 12 / 09$ & 2516 \\
\hline $\begin{array}{l}\text { ACWS } \\
\text { GEM1 }\end{array}$ & $\begin{array}{c}\text { Information } \\
\text { Exchange on } \\
\text { Antifouling } \\
\text { Coatings for War } \\
\text { Ships }\end{array}$ & $\underline{\mathrm{FR}}, \mathrm{UK}, \mathrm{NL}$ & $23 / 11 / 09$ & $\begin{array}{c}\text { Bez } \\
\text { kontraktu - } \\
\text { výměna } \\
\text { informací }\end{array}$ & 0 \\
\hline $\begin{array}{l}\text { TELLUS } \\
\text { IAP2 }\end{array}$ & $\begin{array}{c}\text { Technology } \\
\text { Enablers for } \\
\text { Light \& Low } \\
\text { cost } \\
\text { Urban RF } \\
\text { Systems }\end{array}$ & $\begin{array}{c}\text { SE, NL, FI, } \\
\text { IT, ES }\end{array}$ & $26 / 11 / 09$ & $04 / 12 / 09$ & 9030 \\
\hline $\begin{array}{c}\text { FICAPS } \\
\text { ARM }\end{array}$ & $\begin{array}{c}\text { Future } \\
\text { Interoperability } \\
\text { of Camp } \\
\text { Protection } \\
\text { Systems }\end{array}$ & $\underline{\mathrm{DE}}, \mathrm{FR}$ & $10 / 12 / 09$ & $11 / 12 / 09$ & 8017 \\
\hline $\begin{array}{l}\text { MANGA } \\
\text { IAP1 }\end{array}$ & $\begin{array}{l}\text { Manucturable } \\
\text { GaN: SiC } \\
\text { substrates and } \\
\text { GaN epiwafers } \\
\text { supply chain }\end{array}$ & $\begin{array}{c}\text { DE, FR, IT, } \\
\text { SE, UK }\end{array}$ & $16 / 12 / 09$ & $\begin{array}{c}\text { Kontrakt } \\
\text { zatím } \\
\text { nepodepsán. }\end{array}$ & 17123 \\
\hline $\begin{array}{l}\text { CEDS } \\
\text { GEM1 }\end{array}$ & $\begin{array}{l}\text { Information } \\
\text { Exchange on } \\
\text { Combat } \\
\text { Equipment for } \\
\text { Dismounted } \\
\text { Soldier }\end{array}$ & $\begin{array}{l}\text { FR, AT, ES, } \\
\text { DE, FI, IT, } \\
\text { PT, RO, SE }\end{array}$ & $18 / 12 / 09$ & $\begin{array}{c}\text { Bez } \\
\text { kontraktu - } \\
\text { výměna } \\
\text { informací }\end{array}$ & 0 \\
\hline $\begin{array}{c}\text { DUCAS } \\
\text { IAP3 }\end{array}$ & $\begin{array}{c}\text { Detection in } \\
\text { Urban scenarios } \\
\text { using } \\
\text { Combined } \\
\text { Airborne } \\
\text { imaging Sensos }\end{array}$ & $\begin{array}{l}\text { SE, BE, DE, } \\
\text { FR, IT, NL, } \\
\quad \text { NO, SE }\end{array}$ & $18 / 12 / 09$ & $\begin{array}{l}\text { Národní } \\
\text { kontrakty }\end{array}$ & 6496 \\
\hline $\begin{array}{l}\text { ERM } \\
\text { GEM2 }\end{array}$ & $\begin{array}{c}\text { Environmentally } \\
\text { Responsible } \\
\text { Munitions }\end{array}$ & $\begin{array}{l}\underline{\mathrm{UK}}, \mathrm{FR}, \\
\mathrm{NL}, \mathrm{NO}, \\
\mathrm{RO}\end{array}$ & $22 / 12 / 09$ & $\begin{array}{l}\text { Národní } \\
\text { kontrakty }\end{array}$ & 2210 \\
\hline & & & & & $\begin{array}{c}\text { CELKEM: } \\
130952\end{array}$ \\
\hline
\end{tabular}

Zdroj: EDA Annual Report on R\&T Activities - 2009, European Defence Agency, 17. března 2010, s. 10 (přetištěno se souhlasem EDA). 
Tabulka: Projekty kategorie B ukončené v roce $2009^{45}$

\begin{tabular}{|c|c|c|c|c|}
\hline $\begin{array}{l}\text { Zkratka } \\
\text { projektu/ } \\
\text { CapTech }\end{array}$ & Název projektu & $\begin{array}{l}\text { Účastnické } \\
\text { státy }\end{array}$ & $\begin{array}{l}\text { Datum poslední } \\
\text { faktury }\end{array}$ & $\begin{array}{l}\text { Hodnota projektu } \\
\text { v tis. eur (včetně } \\
\text { DPH a } \\
\text { spolufinancování) }\end{array}$ \\
\hline $\begin{array}{l}\text { TEMPO } \\
\text { IAP1 }\end{array}$ & $\begin{array}{l}\text { Technologies for } \\
\text { the } \\
\text { Miniaturisation } \\
\text { and } \\
\text { the Packaging of } \\
\text { True Time Delay } \\
\text { Modules }\end{array}$ & IT, FI & 22/01/09 & 3720 \\
\hline $\begin{array}{l}\text { MEMS2 } \\
\text { IAP1 }\end{array}$ & $\begin{array}{c}\text { MEMS for } \\
\text { Microwave } \\
\text { Military Systems }\end{array}$ & IT, FR & 28/01/09 & 5088 \\
\hline $\begin{array}{l}\text { TRAM } \\
\text { GEM1 }\end{array}$ & $\begin{array}{c}\text { Development of } \\
\text { new Transparent } \\
\text { Materials } \\
\text { for armour } \\
\text { Applications }\end{array}$ & CZ, IT, NL & 26/05/09 & 4568 \\
\hline $\begin{array}{l}\text { RAPTORS } \\
\text { GEM1 }\end{array}$ & $\begin{array}{l}\text { Radar Absorbing } \\
\text { Paint to Reduce } \\
\text { Signature }\end{array}$ & IT, CZ & $11 / 06 / 09$ & 2411 \\
\hline $\begin{array}{c}\text { SCOOBIDOO } \\
\text { ESM3 }\end{array}$ & $\begin{array}{l}\text { Satel.Chain for } \\
\text { Op. } \\
\text { Oceanography } \\
\text { Based } \\
\text { on Imagery and } \\
\text { Radar Data over } \\
\text { Oceans }\end{array}$ & $\mathrm{FR}, \mathrm{NO}$ & $15 / 10 / 09$ & 4263 \\
\hline $\begin{array}{l}\text { MORSE } \\
\text { IAP1 }\end{array}$ & $\begin{array}{l}\text { Multifunctional } \\
\text { Optical } \\
\text { Reconfigurable } \\
\text { Scalable } \\
\text { Equipment }\end{array}$ & IT, SE, UK & 18/11/09 & 4596 \\
\hline $\begin{array}{l}\text { KORRIGAN } \\
\text { IAP1 }\end{array}$ & $\begin{array}{l}\text { Key Organisation } \\
\text { for Research on } \\
\text { Integrated } \\
\text { Circuits in GaN } \\
\text { Technology }\end{array}$ & $\begin{array}{l}\text { FR, DE, ES, } \\
\text { IT, NL, SE, } \\
\text { UK }\end{array}$ & $25 / 11 / 09$ & 47423 \\
\hline \multirow[t]{2}{*}{$\begin{array}{l}\text { OSEMINTI } \\
\text { IAP4 }\end{array}$} & $\begin{array}{l}\text { Operational } \\
\text { Semantic } \\
\text { Intelligence } \\
\text { Infrastructure }\end{array}$ & FR, ES, UK & 03/12/09 & 6409 \\
\hline & & & & $\begin{array}{l}\text { CELKEM: } \\
78476\end{array}$ \\
\hline
\end{tabular}

Zdroj: EDA Annual Report on R\&T Activities - 2009, European Defence Agency, 17. března 2010, s. 11 (přetištěno se souhlasem EDA). 
programu přispěla částkou 600 tisíc eur, přičemž v roce 2009 VOP-026 Šternberk, s. p., získal jako spoluřešitel v rámci projektu DAFNE (o celkové výši cca 3,07 mil. eur) zakázku na vývoj zařízení ke sběru a syntéze dat se zaměřením na bojiště v urbanizovaném prostředí v hodnotě 672 tis. eur, tzn. $112 \%$ vkladu ČR do programu. ${ }^{46} \mathrm{~V}$ pořadí druhý a zatím poslední JIP s názvem Inovační koncepty a rodící se technologie (Innovative Concepts and Emerging Technologies - ICET) byl schválen Ř́dícím výborem EDA na úrovni ministrů obrany v květnu 2008. ${ }^{47}$ Programu s rozpočtem cca 15,5 mil. eur se účastní 10 členských států EDA (CY, DE, ES, FR, GR, HU, IT, PL, SI a SK) a Norsko. ${ }^{48}$ Cílem programu je zkoumat nanotechnologické materiály a struktury, možnosti dálkové detekce a způsoby monitorování zdraví. ${ }^{49}$

Vlastní příprava společných R\&T projektů probíhá v pracovních skupinách ředitelství EDA pro R\&T, které se pracovně nazývají CapTech (Capability Technology). Existuje 12 CapTech složených ze zástupců EDA a členských států, z nichž se každý soustředí na určitou oblast rozvoje obranných schopností a na technologie, které jsou s touto oblastí spojené. ${ }^{50} \mathrm{~V}$ praxi pak v závislosti na identifikovaných potřebách rozvoje obranných schopností CapTechs navrhují technologická řešení, s jejichž pomocí je možné identifikované potřeby uspokojit. Tato řešení jsou pak předmětem společných R\&T projektů.

\section{Graf: Vývoj R\&T projektů EDA v letech 2007-2009 (hodnota v tis. EUR)}

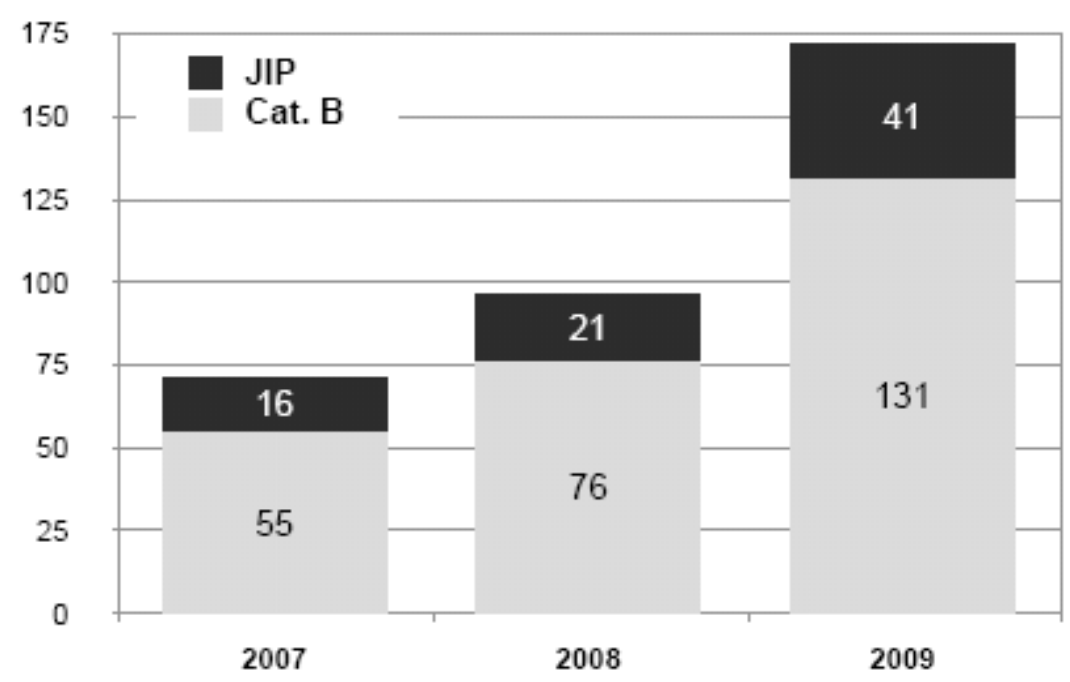

Zdroj: BRÉANT, Christian, Five Years of EDA Collaborative Defence R\&T, s. 8 (přetištěno se souhlasem EDA).

\section{Strategie Evropské spolupráce ve vyzbrojování}

Podpora a zvýšení spolupráce ve vyzbrojování je jednou ze stěžejních aktivit EDA. S cílem maximalizovat př́ležitosti pro spolupráci a postavit realizaci společných projektů na systematickém základě schválil Řídící výbor EDA na úrovni národních ředitelů pro vyzbrojování v říjnu 2008 Strategii Evropské spolupráce ve vyzbrojování. ${ }^{51}$ Strategie vychází z poznání, že snižování obranných rozpočtů, rostoucí náklady na pořízení obranných zařízení a klesající počet zařízení, které je požadováno a produkováno, vyžaduje z hlediska času a nákladů efektivnější způsob naplňování obranných schopností pro plnění úkolů vyplývajících z CSDP. Strategie obhajuje bezpečnostní, vojenské, ekonomické, technologické a průmyslové prrínosy, které jsou spojené s projekty vyzbrojování včetně naplnění požadavků na obranné schopnosti, zlepšení interoperability, otevření exportních přiležitostí, posílení EDTIB a posílení mezinárodní 
spolupráce. S cílem podporovat a zlepšit spolupráci ve vyzbrojování k podpoře CDSP Strategie definuje tři strategické záměry: Strategický záměr 1 - Vytvářet, podporovat a usnadňovat společné projekty k zajištění obranných potřeb, Strategický záměr 2 - Zajistit, aby EDTIB a investice do ní byly zaměřeny na obranné schopnosti a podporovaly budoucí společné projekty, Strategický záměr 3 - Zlepšit efektivitu evropské spolupráce ve vyzbrojování vytvořením správných nástrojů k dosažení cíle. ${ }^{52}$

\section{Schéma: Průvodce realizace př́pravné fáze projektu (návrh) ${ }^{53}$}

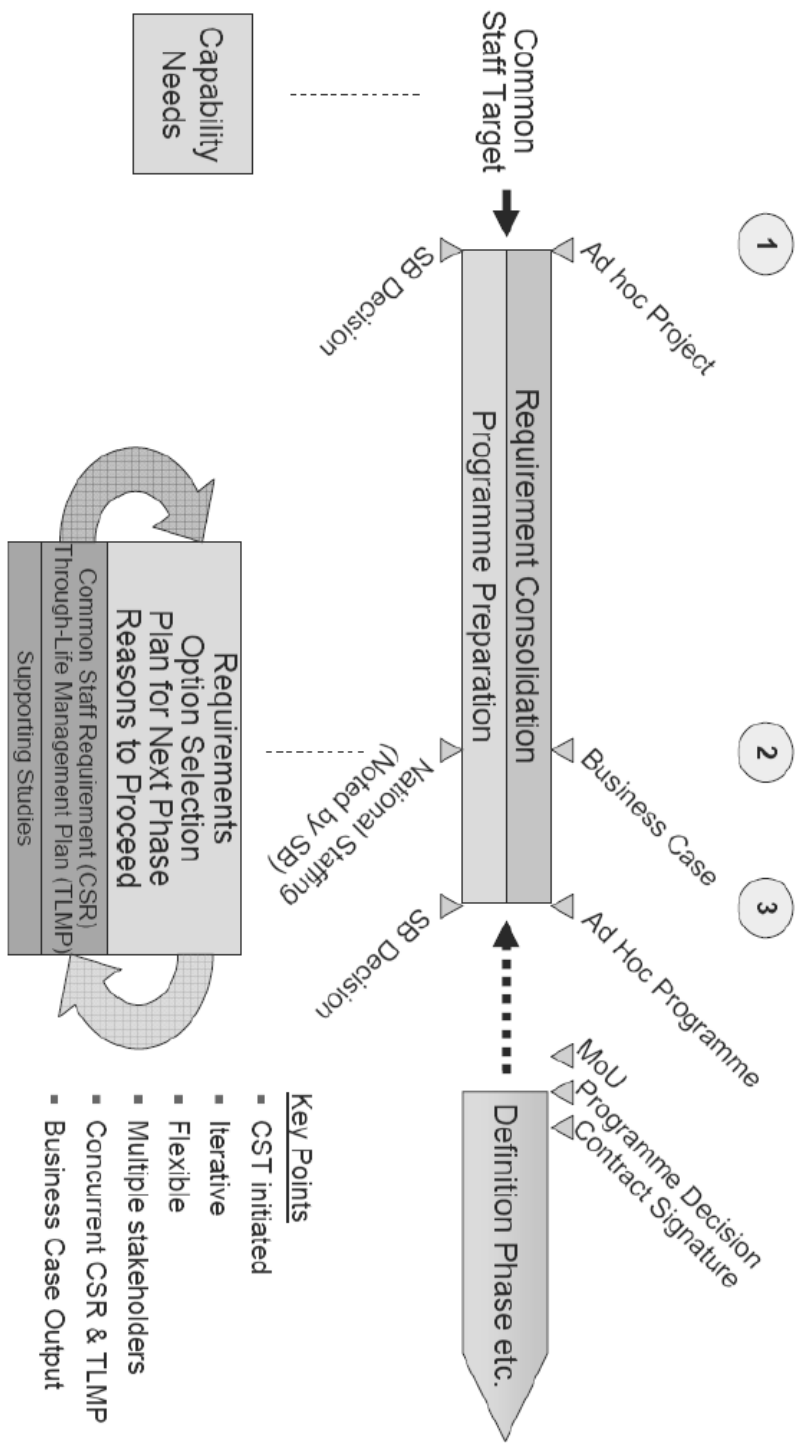

Zdroj: Guide to the Conduct of a Programme Preparation Phase (Draft 4), European Defence Agency, URL: <http://www.eda.europa..eu/genericitem.aspx?area=Organisation\&id=108> (přetištěno se souhlasem EDA). 
Strategický záměr 1 se soustředí na vytvoření podmínek pro realizaci projektů vyzbrojování. Tyto podmínky mají podobu tzv. strukturovaného procesu, který má být blíže specifikován v připravovaném Průvodci realizace přípravné fáze projektu (Guide to the Conduct of a Programme Preparation Phase). ${ }^{54}$ Př́ípravná fáze začíná zadáním uživatelského požadavku (Common Staff Targets - CST) na rozvoj konkrétní obranné schopnosti bud' na základě CDP (např. prostř̌ednictvím databáze $\mathrm{CoDaBa}$ ), nebo na základě iniciativy členských států EDA, a jeho transformací do zadaní společného projektu. Následuje fáze harmonizace požadavků v podobě vypracování studie uživatelské potřeby (Common Staff Requirements - CSR) a příprava obchodního př́ípadu (Business Case) obsahující rozvahu práce/náklady (Work-share/Cost-share). Poslední fází přípravy projektu v EDA představuje definiční fáze, v rámci které je projekt blíže specifikován a předán k vlastní realizaci specializované organizaci nebo agentuře. Strategický záměr 1 pak doplňují dvě zásady: neduplikovat společné projekty a posoudit možnost získat dané obranné zařízení formou společného projektu vyzbrojování již v první fázi úvah o jeho pořízení. ${ }^{55}$

Strategický záměr 2 hovoří pro zaměření EDTIB a investic do EDTIB na budování požadovaných obranných schopností a podporu společných projektů vyzbrojování. Znamená to především zlepšení vzájemné informovanosti mezi průmyslem, EDA a členskými státy o budoucích požadavcích na obranné schopnosti, projektech vyzbrojování, investicích a krocích vedoucích ke konsolidaci průmyslu. Součástí tohoto záměru je i zlepšení transparentnosti a konvergence akvizičních politik a procesů včetně plánování a financování. ${ }^{56}$ Strategický záměr 3 se pak soustředí na zlepšení efektivity evropské spolupráce ve vyzbrojování. Do tohoto záměru patří vytvoření Průvodce nejlepší praxe spolupráce ve vyzbrojování (Guide to Armaments Co-operation Best Practice), sestavení návodu spolupráce s organizacemi nebo agenturami realizujícími projekty vyzbrojování, vytvoření společného porozumění voblasti spolupráce ve vyzbrojování prostřednictvím výcviku a vzdělávání, kodifikace nejlepší praxe v oblasti obranné materiálové standardizace a implementace Koncepčního Průvodce obranné testovací a vyhodnocovací základny (DTEB Conceptual Guide). ${ }^{57}$

\section{... a současné hlavní projekty EDA v oblasti vyzbrojování}

Jak vyplývá ze Strategie EACS, aktivity EDA voblasti př́ípravy společných projektů vyzbrojování se primárně soustředí na přípravnou fázi projektu, zejména pak na definici CST, CSR a přípravu obchodního případu. Realizační fáze projektu, která je zahájena po skončení přípravné fáze, pak je, nebo přesněji řečeno bude, v kompetenci specializované organizace nebo agentury. Žádný ze společných projektů vyzbrojování, který je připravován v EDA, totiž zatím nepokročil do realizační fáze, a tudíž nedošlo k přesunu takovéhoto projektu z Agentury do jiné organizace. Snaha o přenesení realizační fáze projektu na specializovanou organizaci nebo agenturu vychází z poznání, že EDA se současným počtem přibližně 110 pracovníků zajišt’ujících celkový chod Agentury není kapacitně a znalostně schopná zajistit realizaci komplexních projektů vyzbrojování $\mathrm{z}$ vlastních zdrojů. EDA $\mathrm{v}$ této souvislosti připravuje uzavření administrativní dohody (Administrative Arrangement - AA) s Organizací pro spolupráci ve vyzbrojování (Organisation Conjointe de Coopération en matière d'Armement - OCCAR). OCCAR je mezinárodní organizací založenou v roce 1996 s cílem spravovat a řídit společné evropské projekty vyzbrojování. Členskými státy OCCAR jsou BE, DE, ES, FR, IT a UK a vybraných projektů se účastní i jiné státy (NL, PL, SE a TR). V současnosti OCCAR realizuje sedm projektů: zaměřovací radar COBRA, víceúčelový vrtulník TIGER, rodina systémů protivzdušné obrany se středním a dlouhým doletem FSAF, víceúčelové kolové vozidlo BOXER, letoun A400M, fregatu FREMM a softwarové rádio ESSOR ${ }^{58}$ Vzhledem ke zkušenosti se společnými projekty vyzbrojování, kapacitě a znalostní bázi se OCCAR zdá být pro EDA přirozeným partnerem. ${ }^{59}$

Prvním velkým společným projektem vyzbrojování, který je připravován v EDA, je plánován $\mathrm{k}$ předání OCCAR a jenž je současně prvním zkušebním případem možné spolupráce mezi EDA a OCCAR, je projekt kategorie $\mathrm{B}$ na Vývoj zařízení pro detekci, identifikaci a monitoring 
biologických látek - přípravná fáze (Identification Monitoring Equipment Development and Enhancement Programme - BIO EDEP Prep.). Projektu BIO EDEP Prep. schváleného Ř́dícím výborem EDA na úrovni ministrů obrany v květnu 2009 se účastní devět členských států EDA včetně ČR (BE, DE, FR, ES, IT, NL, PL a SE) a Norsko. Cílem projektu je připravit studii uživatelské potřeby (CSR) pro individuální ochranu vojáka nasazeného v rámci účelového uskupení (Task Force) před účinky biologických látek, ochranu vševojskových jednotek a speciálních jednotek CBRN a podložit ji obchodním případem obsahujícím rozvahu práce/náklady na vývoj jednotlivých komponent zařízení, které budou vyvíjeny v rámci návazného projektu Obranného systému biologického průzkumu (Biological Integrated Reconnaissance Defence System - BIRD) od roku 2011-2012 v rámci OCCAR. ${ }^{60}$

Mezi další činnosti EDA v oblasti vyzbrojování, které souvisí s implementací Strategie EACS i realizací konkrétních projektů vyzbrojování, patří harmonizace materiálové standardizace. Tato problematika se zaměřuje především na vývoj Evropského informačního systému o obranné standardizaci (European Defence Standards Information System - EDSIS) a vývoj Evropské příručky pro zakázky v obraně (European Handbook for Defence Procurement - EHDP), která obsahuje souhrn standardů „nejlepší praxe“ užívaných při zakázkách v obraně ve vybraných technických oblastech. ${ }^{61}$ Další činností EDA v oblasti vyzbrojování je vzdělávání ve vyzbrojování, jejímž cílem je zlepšit efektivitu společných projektů vyzbrojování. Prostředkem k dosažení tohoto cíle je vytvoření společné evropské platformy výcviku a vzdělávání v oblasti př́ípravy a realizace společných projektů vyzbrojování zaměřené primárně na projektové manažery. ${ }^{62}$ Mezi oblasti s návazností na Strategii EACS je možné zařadit i problematiku Obranné zkušební a vyhodnocovací základny (Defence Test and Evaluation Base - DTEB). EDA se v této oblasti soustředí na posouzení způsobů racionalizace využíání stávajících obranných zkušebních a vyhodnocovacích zařízení. ${ }^{63}$

Významnou aktivitou EDA v oblasti vyzbrojování je i harmonizace certifikačních procesů v oblasti vojenské letové způsobilosti (European Military Airworthiness Requirements - EMARs). Oblast vojenské letové způsobilosti (Military Airworthiness) je na rozdíl od civilní letové způsobilosti nekoordinovaná a neexistuje žádné formální ujednání, opatření nebo procedura, která by garantovala společný př́stup v této otázce. V důsledku toho je vojenská letová způsobilost regulována jen na národní úrovni v rámci individuálních projektů, což je časově i finančně náročné, a ve svém důsledku výrazně zpomaluje a prodražuje realizaci souvisejících společných projektů. EDA má ambici zastřešit koordinaci aktivit $\mathrm{v}$ oblasti harmonizace vojenské letecké způsobilosti s tím, že hlavní odpovědnost za normotvorbu a regulaci této oblasti zůstane u členských států. Prvním krokem k naplnění této ambice bylo vytvoření evropského fóra pro vojenskou letovou způsobilost (EDA Military Airworthiness Forum - EDA MAWA Forum) pod patronací EDA, k jehož ustavení EDA vypracovala cestovní mapu, která byla schválena spolu s MAWA rozhodnutím Řídícího výboru EDA na úrovni ministrů obrany v listopadu $2008 .{ }^{64}$ Od MAWA se očekává, že se stane hlavním evropským koordinačním orgánem voblasti vojenské letové způsobilosti a hlavním aktérem při vývoji EMARs.

\section{Strategie Evropské obranné technologické a průmyslové základny}

Posledním a zároveň nejstarším z dokumentů tvořících Strategický rámec EDA je Strategie Evropské obranné technologické a průmyslové základny, která byla přijata Řídícím výborem EDA na úrovni ministrů obrany v květnu $2007 .^{65}$ Strategie vyzdvihuje potřebu vytvoření silné EDTIB schopné rychle, efektivně a hospodárně plnit požadavky ozbrojených sil členských států EDA a vybavit je výstrojí, výzbrojí a zařízeními nutnými k plnění úkolů vyplývajících z CSDP. Klesající výdaje na obranu, rostoucí náklady a komplexita obranných zařízení, zesílená konkurence na zahraničních trzích zejména v USA a v Asii pak zásadně ovlivňují způsob naplnění této potřeby. Strategie vychází z předpokladu, že budoucí potřeby ozbrojených sil členských států EDA nebude možné zajistit výlučně na národní bázi, ale pouze na základě EDTIB, která bude více než sumou 
jejich národních částí, tzn. více integrovaná, méně duplicitní, více vzájemně závislá a specializovaná. Taková EDTIB bude vedena obrannými schopnostmi (Capability-driven), tzn. (zaměřena na dosažení reálných operačních požadavků ozbrojených sil), kompetentní (Competent), tzn. (schopná rychle využít nejlepších dostupných technologií) a konkurenceschopná (Competitive) v rámci EU i za jejími hranicemi. ${ }^{66}$

Aby bylo možné takovou EDTIB vytvořit, je třeba podle Strategie EDTIB seřadit priority rozvoje obranných schopností, jak bylo učiněno v rámci CDP, identifikovat klíčové technologie, jak bylo provedeno v rámci Strategie EDRT, a identifikovat klíčové průmyslové kapacity. Dále je třeba konsolidovat poptávku tak, aby byla vedena obrannými schopnostmi (v kontextu implementace CDP), zvýšit investice, alokovat více prostř̌edků na výzkum a technologie (v souladu s implementací Strategie EDRT), zajistit bezpečnost dodávek (SoS) operacionalizací Rámcové dohody o bezpečnosti dodávek v případě operační nutnosti schválené Řídícím výborem EDA na úrovni národních ředitelů pro vyzbrojování v září $2006^{67}$ a zvýšit konkurenceschopnost a spolupráci (v rámci implementace Strategie EACS). ${ }^{68} \mathrm{~V}$ oblasti posílení konkurenceschopnosti Strategie vyzdvihuje potřebu vyvarovat se užívání článku 346 zakládající smlouvy o EU, ${ }^{69}$ odstranit bariéry mezi členskými státy pro obchod s vojenským materiálem, uznat, že offsety narušují soutěž, a v dlouhodobé perspektivě vytvořit podmínky, ve kterých offsety nebudou nutné, zajistit rovné podmínky pro všechny účastníky trhu (Level-playing Field - LPF) a zlepšit efektivitu spolupráce ve vyzbrojování (mj. odstranění praxe just retour). ${ }^{70}$

\section{... a současné hlavní projekty EDA v oblasti průmyslu a trhu}

V oblasti průmyslu a trhu EDA se projekty jako takové zatím nevyskytují. Jde spíše o politiky nebo iniciativy, které jsou rámci implementace Strategie EDTIB v EDA rozvíjeny. Za jednu z nejdůležitějších činností EDA v oblasti průmyslu a trhu lze označit tvorbu Mezivládního režimu pro zakázky v obraně, který směřuje k vytvoření fungujícího EDEM. ${ }^{71} \mathrm{~V}$ současné době existují tři kodexy chování v rámci mezivládních režimů: Kodex chování o zakázkách v obraně (Code of Conduct - CoC), Kodex nejlepší praxe v dodavatelském řetězci (Code of Best Practice in the Supply Chain - CoBPSC) a Kodex chování o Offsetech (Code of Conduct on Offsets - CoC on Offsets). Nejstarším, a tudíž nejdéle fungujícím, kodexem je Kodex chování o zakázkách v obraně, který vstoupil v platnost 1 . července 2006 a pokrývá pořízení obranného materiálu v režimu článku 346 zakládající smlouvy o EU. ${ }^{72}$ Tento článek umožňuje členským státům v případě zajištění podstatných bezpečnostních zájmů státu pořídit vojenský materiál mimo pravidla stanovená Směrnicí EU 2004/18. ${ }^{73}$ S přijetím Kodexu chování se 25 členských států EDA (s výjimkou RO) a Norsko zavázalo publikovat výběrová řízení v režimu článku 346 zakládající smlouvy o EU a celkové hodnotě 1 mil. eur a vy̌šsí v Elektronickém věstníku vládních zakázek (Electronic Bulletin Board - Goverment Contracts - EBB - GC) na webových stránkách EDA. ${ }^{74}$ Kodex chování umožňuje členským státům EDA použít výjimek nadále jen v případě nákupu v rámci společných projektů nebo v oblasti výzkumu a technologií, pořízení jaderných zbraní, chemických, bakteriologických a radiologických zařízení a nákupu kryptografického vybavení. Výjimka se rovněž týká specifických případů, jakými jsou naléhavá operační potřeba, např. pořízení vojenského materiálu pro ozbrojené síly voperacích, následná dodávka zboží nebo služeb a ohrožení podstatných zájmů národní bezpečnosti. ${ }^{75}$

$\mathrm{V}$ pořadí druhým kodexem je Kodex nejlepší praxe $\mathrm{v}$ dodavatelském řetězci, který vstoupil v platnost ve stejný den jako CoC, avšak operacionalizován byl až 29. března 2007, kdy byl spuštěn Elektronický věstník průmyslových zakázek (Electronic Bulletin Board - Industry Contracts - EBB - IC). ${ }^{76}$ CoBPSC rovněž směřuje ke zvýšení transparentnosti a konkurence v obranných zakázkách, avšak na rozdíl od CoC, které je zaměřeno na vládní zakázky, se CoBPSC soustředí na zakázky $\mathrm{v}$ rámci dodavatelského řetězce velkých dodavatelů obranného zařízení (Prime Contractors). ${ }^{77}$ Třetím a zatím posledním kodexem je Kodex chování o offsetech, který byl schválen Řídícím výborem EDA v říjnu 2008 a vstoupil v platnost 1. července 2009 mezi 25 
členskými státy EDA (s výjimkou RO) a Norskem. ${ }^{78}$ V rámci implementace Strategie EDTIB, která mj. usiluje o vytvoření rovných podmínek pro všechny účastníky trhu (LPF), Kodex harmonizuje offsety a stanovením maximální hodnoty offsetového závazku ve výši hodnoty zakázky (tzn. $100 \%$ ) směřuje ke snížení míry jejich negativního dopadu na soutěž a tvorbu EDEM. $^{79}$

Mezi další významné aktivity EDA v oblasti průmyslu a trhu, které mají přímou návaznost na implementaci Strategie EDTIB, patři problematika Budoucích leteckých systémů (Future Air Systems - FAS). FAS, konkrétně pak vrtulníky a UAVs, byly v návaznosti na přijetí Strategie EDTIB identifikovány jako pilotní oblast pro identifikaci klíčových průmyslových schopností a realizaci společných projektů v rámci tvorby EDTIB. Zajištění životaschopného evropského leteckého průmyslu, který je základem FAS a tvoří podstatnou část EDTIB, je považováno EDA a jejími členskými státy za nezbytné pro zachování klíčových průmyslových schopností v EU pro plnění úkolů vyplývajících z CSDP. ${ }^{80}$ Podobně zaměřenou aktivitou EDA je oblast munice (Ammunition Sector), kde se EDA snaží o společný postup v oblasti certifikace, normotvorby a harmonizace požadavků na výrobu munice. EDA identifikovala, že investice do vývoje nové munice v rámci EDTIB jsou nedostatečné ve vztahu k zajištění budoucích potřeb, a hrozí tudíž zvýšená závislost na mimoevropských dodavatelích. To je však z hlediska zajištění operační suverenity EU jako celku nepřijatelné. EDA proto hodlá iniciovat společný postup v uvedených oblastech a zahájit společné projekty v oblasti vývoje nové munice, její certifikace, harmonizace požadavků a tvorby nových předpisů pro nakládání s municí. ${ }^{81}$

Kromě identifikace klíčových průmyslových schopností, které mají být v EU zachovány a dále rozvíjeny, se aktivita EDA v oblasti průmyslu a trhu soustředí i na problematiku zapojení malých a středních podniků (Small and Medium Enterprises - SMEs) do tvorby EDEM. Kromě CoBPSC, který se snaží zprostředkovat př́ležitosti pro SMEs v rámci dodavatelského řetězce velkých dodavatelů, se EDA zaměřuje i na zjednodušení a harmonizaci zadávání veřejných zakázek u zakázek s menší hodnotou (250 000 eur až 412000 eur -1 mil. eur v př́ípadě CoC) a u zakázek v oblasti výzkumu a technologií. V této souvislosti schválil Rídící výbor EDA na úrovni národních ředitelů pro vyzbrojování v říjnu 2009 Návod na zjednodušení přístupu SMEs na obranných trh (Guidelines for Facilitating SME's Access on the Defence Market), který definuje pravidla, která by členské státy EDA měly dodržovat při zadávání veřejných zakázek. ${ }^{82}$ Tato pravidla se týkají výměny informací, dodržování platebních závazků, zajištění překladu zakázky do anglického jazyka, transparentnosti certifikačních kritérií, ochrany duševního vlastnictví a sdílení priorit v oblasti R\&T. ${ }^{83}$

\section{ZÁVĚR - NEJBLIŽŠÍ VÝZVY}

Třebaže se EDA za šest let své existence stala respektovanou organizací schopnou řešit celou škálu otázek souvisejících se snahou o zlepšení obranných schopností EU, čeká na Agenturu v následujícím období hned několik velkých výzev, které prověří její připravenost pokračovat v započatém procesu. V oblasti rozvoje obranných schopností se v nejbližších měsících bude hlavní pozornost EDA soustředit na aktualizaci CDP, jehož nová verze by měla být k dispozici v druhé polovině roku 2010. Vstupy pro aktualizaci CDP budou představovat výsledky práce na mapování možností spolupráce (Landscaping) a na identifikaci zkušeností z operací (Lessons Identified). V případě mapování možností spolupráce půjde o činnost mající za cíl identifikovat nejvhodnější a nejdůležitější možnosti pro realizaci společných projektů, které povedou ke zlepšení obranných schopností. Základem pro tuto činnost bude porovnání celkových (společných evropských) požadavků na rozvoj obranných schopností se současnými a plánovanými národními obrannými schopnostmi. V prŕípadě identifikace zkušeností z operací půjde o zmapování zkušeností ze současných operací, do kterých jsou zapojeny členské státy EU (např. ISAF) nebo probíhají př́ímo pod hlavičkou CSDP (např. ATALANTA). ${ }^{84}$ 
V oblasti výzkumu a technologií se hlavní pozornost EDA bude zaměřovat především na koordinaci aktivit mezi Agenturou, Evropskou komisí (European Commission - CION) a Evropskou vesmírnou agenturou (European Space Agency - ESA). EDA hodlá učinit další krok směrem k lepší synchronizaci obranného výzkumu a propojit jeho realizaci s výzkumem v oblasti vesmíru v rámci ESA a výzkumem v oblasti bezpečnosti v rámci CION prostřednictvím tzv. Evropského rámce spolupráce (European Framework Co-operation - EFC). V této souvislosti EDA hodlá v průběhu roku 2010 iniciovat společné projekty v oblasti CBRN, UAVs a Situačního povědomí (Situation Awareness). ${ }^{85}$ Aby však tato iniciativa mohla přinést očekávaný úspěch v podobě dosažení synergie mezi výzkumnými aktivitami uvedených organizací, snížení nákladů a zlepšení efektivity výzkumu v rámci EU jako celku, bude třeba blíže definovat způsob vzájemné spolupráce a úzce koordinovat př́ípravu a zaměření budoucích projektů. Vzhledem ke skutečnosti, že EDA, CION a ESA mají odlišné právní postavení (ESA není součástí EU), odlišné úkoly, vnitřní mechanismy rozhodování a financování a rovněž odlišnou členskou základnu, lze očekávat, že dosažení synergie $\mathrm{v}$ oblasti výzkumu mezi těmito organizacemi si vyžádá ještě mnoho společného úsilí.

V oblasti vyzbrojování lze za klíčovou výzvu označit formalizaci vztahu mezi EDA a OCCAR, který by se měl v budoucnu stát hlavním realizátorem společných projektů vyzbrojování dohodnutých a připravených v rámci EDA. V závislosti na schválení AA v průběhu roku 2010 a dokončení př́ípravné fáze pilotního projektu vyzbrojování BIO EDEP Prep. bude třeba společně nastavit mechanismy spolupráce dohodnuté v AA a přizpůsobit chod obou organizací nové realitě, zejména s ohledem na zapojení OCCAR do přípravné fáze projektů v EDA a na zapojení EDA do realizační fáze v OCCAR. Současně členské státy EDA, které nejsou členskými státy OCCAR a hodlají se podílet na projektech vyzbrojování v EDA, jež bude OCCAR řídit, musejí uzavřít s OCCAR bilaterální Bezpečností dohodu o ochraně utajovaných informací. Tato dohoda je pro nečlenské státy OCCAR podmínkou pro zapojení do společných projektů vyzbrojování, které OCCAR řídí, a její schválení trvá přibližně 18-24 měsíců. Případná absence takové dohody u státu, který by byl zapojen do přípravné fáze společného projektu vyzbrojování v rámci EDA, jenž má být následně předán OCCAR $\mathrm{k}$ realizaci, by mohla danému státu nejen zabránit $\mathrm{v}$ účasti na projektu, ale ohrozit projekt jako celek.

V oblasti průmyslu a trhu čeká na EDA implementace dalších kroků k realizaci LPF a řešení dalších narušení trhu a jejich dopadů na EDEM a EDTIB, zejména pak otázka vlastnictví podniků obranného průmyslu, podíl státu na jejich řízení, státní pomoc nebo podpora exportu. Současně od října 2010 vstoupí v platnost ustanovení Kodexu chování o offsetech - první narušení trhu, které členské státy identifikovaly a dohodly se na jeho omezení a postupné eliminaci - stanovující, že hodnota offsetového závazku nesmí být vyšší než hodnota zakázky, tzn. maximálně $100 \%{ }^{86}$ $\mathrm{V}$ roce 2010 rovněž začne implementace dvou nově přijatých směrnic CION majících přímý vliv na tvorbu EDEM a EDTIB: Směrnice 2009/43/EC o intrakomunitárním transferu obranného zařízení, která zjednodušuje způsob a podmínky pohybu obranného zařízení v rámci EU, ${ }^{87}$ a Směrnice 2009/81/EC o koordinaci procedur pro udílení veřejných zakázek na práce, dodávky a služby v oblasti obrany a bezpečnosti. ${ }^{88}$ Zatím není zřejmé, jaké kategorie strategického zboží budou vyloučeny $\mathrm{z}$ veřejné soutěže $\mathrm{z}$ důvodu ochrany podstatných bezpečnostních zájmů $\mathrm{v}$ souladu s článkem 346, zakládajícím dokumentem o EU. Otevřená zůstává rovněž otázka způsobu a rozsahu implementace obou směrnic do národního práva členských států EU i vlivu výsledného stavu této implementace na tvorbu EDEM a EDTIB. Navzdory těmto otázkám je zřejmé, že uvedené směrnice přinesou zásadní změnu do způsobu zadávání veřejných závazek v obraně a bezpečnosti i pohybu obranného zařízení v rámci EU. Lze očekávat, že obě směrnice přinesou podstatné zjednodušení obchodu s obranným zařízením v rámci EU a současně zásadně omezí počet prrípadů, kdy bude možné udělit obrannou nebo bezpečnostní zakázku bez otevřené soutěže konkrétním dodavatelům.

Patrně největší výzvou, před níž EDA stojí a se kterou se Agentura bude muset v nejbližší době vypořádat, je implementace Lisabonské smlouvy. EDA je jedinou Agenturou, která je v Lisabonské 
smlouvě výslovně uvedena, což významně zvyšuje její postavení. Lisabonská smlouva převážně kodifikuje současný stav, a třebaže nedefinuje nové úkoly EDA s výjimkou ustanovení ve vztahu EDA vůči Stálé strukturované spolupráci (Permanent Structured Co-operation in Defence - PSCD), vyžaduje, aby Evropská rada kvalifikovanou většinou přijala (nové) rozhodnutí o statutu, sídle a operačních pravidlech Agentury. ${ }^{89}$ Takové rozhodnutí by mělo v principu sloučit text Společné akce, kterou byla EDA před šesti lety založena a jejíž text byl odvozen od tehdejšího textu Smlouvy o ústavě pro Evropu, s textem Lisabonské smlouvy. ${ }^{90}$ Dosavadní diskuse však ukázala, že ne všechny členské státy EDA tuto variantu jednoznačně podporují. Řada států se snaží využít příležitosti k prosazení svých partikulárních zájmů a spojit přijetí nového rozhodnutí Rady o EDA s revizí textu Společné akce v otázce rozsahu pravomocí nad jednotlivými oblastmi, které EDA řeší, především pak v oblasti výzkumu a technologií a průmyslu a trhu, kde je aktivní CION. Dále v otázkách finančních, personálních i organizačně-administrativních, jako je např. revize ustanovení o tříletém finančním rámci, který se doposud nepodařilo prrijmout, nebo otázka zachování dvou zástupců výkonného ředitele EDA. Přestože většina členských států se kloní k potvrzení původního textu Společné akce a podporuje jeho dílčí aktualizaci jen s ohledem na obsah Lisabonské smlouvy, lze očekávat, že přijetí nového rozhodnutí Rady o EDA budou předcházet dlouhá a složitá jednání. Ačkoliv současný výkonný ředitel EDA usiluje o brzké přijetí nového rozhodnutí Rady a o návrat k plnění hlavního poslání EDA v oblasti rozvoje obranných schopností, je pravděpodobné, že do konce jeho funkčního období v září 2010 nové rozhodnutí Rady nebude přijato. Vymezení ,staronové“ úlohy Agentury v nové architektuře CSDP EU se tak patrně stane až prvním důležitým úspěchem jeho nástupce.

\section{POZNÁMKY}

\footnotetext{
${ }^{1} \mathrm{~S}$ výjimkou Dánska, které není zapojeno do činnosti EDA.

${ }^{2}$ Dříve Evropská obranná a bezpečnostní politika (ESDP). Viz Společná akce Rady 2004/551/SZBP ze dne 12. července 2004 o zř́zení Evropské obranné agentury, Úřední věstník Evropské unie, L 245/17, 17. července 2004, Článek 2.

${ }^{3}$ Viz KOLÍN, Vilém, Evropská obranná agentura po třech letech, s. 73-85.

${ }^{4}$ WEIS, Alexander, Project, Project, Project, s. 1.

${ }^{5}$ Viz Společná akce Rady 2004/551/SZBP ze dne 12. července 2004 o zř́zení Evropské obranné agentury, Článek 5.

6 Viz JORDAN, Graham; WILLIAMS, Tim, Hope Deferred? The European Defence Agency after Three Years, s. 66.

${ }^{7} \mathrm{~S}$ ohledem na lepší srozumitelnost a terminologickou nejednotnost českého překladu je diagram ponechán $\mathrm{v}$ původním anglickém znění.

${ }^{8}$ Viz An Initial Long-Term Vision for European Defence Capability and Capacity Needs, European Defence Agency, 3. ř́jna 2006.

${ }^{9}$ Viz Future Trends from the Capability Development Plan, European Defence Agency, 21. října 2009, s. 5.

${ }^{10}$ Viz A Secure Europe in a Better World, European Security Strategy, 12. prosince 2003.

${ }^{11}$ Viz ibid., s. 12.

${ }^{12}$ Viz Proposed Conclusions from the Capability Development Plan, European Defence Agency, EDA Document No. 2008/26, 8. července 2008.

${ }^{13} \mathrm{Viz}$ Future Trends from the Capability Development Plan, s. 6.

${ }^{14}$ Viz ibid.

${ }^{15}$ Viz Identified Collaborative Opportunities in the CDP Collaborative Database, European Defence Agency, EDA Document No. 2008/28, 8. července 2008.

${ }^{16}$ Viz European Helicopter Training Programme (HTP) Concept, European Defence Agency, EDA Document No. 2009/35, 17. listopadu 2010.

${ }^{17}$ Viz ibid.

${ }^{18}$ Viz Interim Synthetic Helicopter Tactics Course, European Defence Agency, Steering Board Decision No. 2009/40, 27. ř́jina 2009.
} 
${ }^{19}$ Viz Multinational Space-Based Imaging System, European Defence Agency, Steering Board Decision No. 2009/01, 3. března 2009.

${ }^{20}$ Viz European Satellite Communication Procurement Cell (ESCPC), European Defence Agency, Steering Board Decision No. 2009/34, 15. ř́jna 2009.

${ }^{21}$ Viz Midair Collision Avoidance System for UAV/UCAV - (MIDCAS), European Defence Agency, Steering Board Decision, No. 2008/19, 17. června 2008.

${ }^{22}$ Viz Maritime Mine Counter-Measures, European Defence Agency, Steering Board Decision, No. 2008/35, 10. listopadu 2008; a Future Unmanned Aerial Systems (FUAS), European Defence Agency, Steering Board Decision No. 2008/36, 10. listopadu 2008.

${ }_{23}$ Viz European Secured Software Defined Radio Referential (ESSOR), European Defence Agency, Communication No. 07/09, 24. ledna 2007, a Communication No. 06/24, 9. března 2007.

${ }^{24}$ Viz European Air Transport Fleet, EDA Note for the Steering Board No. 2009/62, European Defence Agency, 6. listopadu 2009.

${ }^{25}$ Viz Defence Ministers Launch European Helicopter Training, European Defence Agency, Press Release, 17. listopadu 2009.

${ }^{26}$ Viz Establishment of the European Third Party Logistic Support (TPLS) Platform, European Defence Agency, Steering Board Decision No. 2009/14, 2. dubna 2009.

${ }^{27}$ Viz EU Third Party Logistic Support Platform Officially Launched, European Defence Agency, Press Release, 1. července 2009.

${ }_{28}$ Zatímco Integrovaných rozvojových týmů je celkem šest (IDT Command, IDT Deploy, IDT Engage, IDT Inform, IDT Protect a IDT Sustain), jim podřízených projektových týmů zaměřených na konkrétní projekty je v současnosti přibližně 20.

${ }^{29}$ Viz The Approval of a European Defence Research and Technology Strategy, European Defence Agency, Steering Board Decision No. 2008/34, 10. listopadu 2008.

${ }^{30}$ Viz A European Defence Research and Technology Strategy, European Defence Agency, 13. února 2009, s. 1.

${ }^{31}$ Viz ibid.

${ }^{32}$ Viz ibid; a Collective Benchmarks, European Defence Agency, EDA Document No. 2007/13, 19. listopadu 2007. Vedle srovnávacích kolektivních ukazatelů v oblasti R\&T byly schváleny i srovnávací ukazatele pro podíl pořízení obranného materiálu a služeb (včetně $R \& D / R \& T$ ) na celkových výdajích na obranu na hodnotu $20 \%$ a pro podíl společného pořízení obranného materiálu a služeb v rámci EU na celkových výdajích na pořízení materiálu a služeb na hodnotu $35 \%$.

${ }^{33}$ Viz A European Defence Research and Technology Strategy.

${ }^{34} \mathrm{Viz}$ The Approval of a European Defence Research and Technology Strategy.

${ }^{35}$ Viz ibid.

${ }^{36}$ Viz ibid.

${ }^{37}$ Viz A European Defence Research and Technology Strategy, s. 7-8.

${ }^{38}$ Viz Společná akce Rady 2004/551/SZBP ze dne 12. července 2004 o zř́izení Evropské obranné agentury, Článek 21.

${ }^{39}$ Viz European Defence Agency, EDA Achievements since 2004, s. 5.

${ }^{40}$ Viz EDA Annual Report on R\&T Activities - 2009, European Defence Agency, 17. března 2010, s. 10.

${ }^{41}$ Viz ibid., s. 11.

${ }^{42}$ Viz Defence R\&T Joint Investment Programme on Force Protection, European Defence Agency, Steering Board Decision No. 2006/33, 13. listopadu 2006.

${ }^{43}$ Viz ibid.

${ }^{44} \mathrm{~S}$ ohledem na lepší srozumitelnost a terminologickou nejednotnost českého překladu jsou názvy projektů uvedené $\mathrm{v}$ tabulce ponechány v původním anglickém znění.

${ }^{45} \mathrm{~S}$ ohledem na lepší srozumitelnost a terminologickou nejednotnost českého překladu jsou názvy projektů uvedené v tabulce ponechány v původním anglickém znění.

${ }^{46} \mathrm{Viz}$ Selection of Proposals to Be Contracted and on the Negotiation Mandate for the 3rd Call for Proposals of the JIP-FP, European Defence Agency, JIP-FP Management Committee Decision No. 2008/19, 16. prosince 2008.

${ }^{47}$ Viz Innovative Concepts and Emerging Technologies (ICET), European Defence Agency, Steering Board Decision No. 2008/17, 26. května 2008.

${ }^{48}$ Viz ibid. 
${ }^{49}$ Viz ibid.

${ }^{50} 12$ existujících Captech je rozděleno do 3 hlavních skupin, které reflektují hlavní oblasti rozvoje schopností: IAP (Zisk informací a jejich zpracování) - znalost; GEM (Navádění, energie a materiály) - zapojení; ESM (Prostředí, systémy a modelování) - manévr. IAP se dále dělí na IAP 1-4 (Components; RF Sensor System and Signal Processing; Optical Sensor System and Signal Processing; CIS and Networks). GEM se dále dělí na GEM 1-4 (Materials and Structures; Energetics, Missiles and Munitions; Ground Systems and their Enviroment; Guidance and Control). ESM se dále dělí na ESM 1-4 (Naval Systems and their Environment; Aerial Systems and their Environment; Systems of Systems, Space, Simulation and Experiment; Human Factors and CBR Protection). Viz Key Operating Rules for the R\&T Operational Concept, European Defence Agency, Steering Board Decision No. 2008/13, 8. dubna 2008.

${ }^{51}$ Viz A European Armaments Co-operation Strategy, European Defence Agency, Steering Board Decision No. 2008/32, 15. ř́jna 2008.

${ }^{52}$ Viz European Armaments Co-operation Strategy, European Defence Agency, 13. února 2009, s. 7-10.

${ }^{53} \mathrm{~S}$ ohledem na lepší srozumitelnost a terminologickou nejednotnost českého překladu je text diagramu ponechán v původním anglickém znění.

${ }^{54}$ Viz ibid., s. 7.

${ }^{55}$ Viz ibid., s. 8.

${ }^{56}$ Viz European Armaments Co-operation Strategy, s. 8-9.

${ }^{57}$ Viz ibid., s. 9-10; Defence Test \& Evaluation Base Conceptual Guide, European Defence Agency, Steering Board Decision No. 2008/29, 15. ř́jna 2008; a Guide to Conduct of Preparation Phase, European Defence Agency, Steering Board Decision No. 2008/30, 15. ř́ína 2008.

${ }^{58}$ Seznam aktuálních projektů OCCAR je k dispozici na URL: <http://www.occar-ea.org/view.php?nid=72>.

${ }^{59}$ Viz SCHMITT, Andreas, EDA und OCCAR - Starke Partner für Europas Streitkräfte, s. 18-22.

${ }^{60}$ Viz Biological Equipment Development and Enhancement Programme - Preparation Phase - BIO EDEP, European Defence Agency, Steering Board Decision No. 2009/21, 18. května 2009.

${ }^{61}$ Souhrnné informace EDA k problematice obranné materiálové standardizace jsou k dispozici na URL: $<\mathrm{http}: / /$ www.eda.europa.eu/genericitem.aspx?Area=Organisation\&ID=577>. Portál EDSIS je k dipozici na URL: <http://www.eda.europa.eu/edsisweb> a portál EHDP na URL: <http://www.defense-handbook.org>.

${ }^{62}$ Souhrnné informace EDA k problematice vzdělávání ve vyzbrojování jsou k dispozici na URL: $<\mathrm{http}: / /$ www.eda.europa.eu/genericitem.aspx?Area=Organisation\&ID=579>.

${ }^{63}$ Souhrnné informace EDA k problematice obranné zkušební a vyhodnocovací základně jsou k dispozici na URL: <http://www.eda.europa.eu/genericitem.aspx?Area=Organisation\&ID=583>.

${ }^{64}$ Viz Road Map on an EU-wide Forum for MAWA, European Defence Agency, Steering Board Decision No. 2008/39.

${ }^{65}$ Viz A Strategy for the European Defence Technological and Industrial Base, European Defence Agency, Steering Board Decision No. 2007/11, 14. května 2007.

${ }^{66}$ Viz ibid.

${ }^{67}$ Viz Framework Arrangement for Security of Supply Between Subscribing Member States (sMS) in Circumstance of Operational Urgency, European Defence Agency, Steering Board Decision No. 2006/17, 20. záŕí 2006.

${ }^{68}$ Viz A Strategy for the European Defence Technological and Industrial Base.

${ }^{69}$ Dříve článku 296 Smlouvy o Evropském společenství.

${ }^{70}$ Viz ibid. Juste Retour je praxe obvyklá při společných projektech vyzbrojování, která pro participující stát znamená, že jeho průmyslový podíl na projektu se rovná jeho podílu na nákupu výsledného produktu. Jinými slovy, národní náklady na nákup výsledného produktu se rovnají národní průmyslové účasti na projektu.

${ }^{71} \mathrm{~K}$ obecnému úvodu do problematiky EDEM viz e.g. MEIRIÑO, Arturo Alfonso, El nuevo marco Europeo para el mercado de la Defensa, s. 44-49.

${ }^{72}$ Viz Treaty of Lisbon Amending the Treaty of the European Union and the Treaty Establishing the European Community, Official Journal of the European Union, C 306, 17. prosince 2007, článek. 346.

${ }^{73}$ Elektronický věstník vládních zakázek je př́stupný na na URL: <http://www.eda.europa.eu/ebbweb>.

${ }^{74}$ Souhrnné informace EDA k problematice elektronického věstníku vládních zakázek jsou $\mathrm{k}$ dispozici na URL: <http://www.eda.europa.eu/genericitem.aspx?Area=Organisation\&ID=153>.

${ }^{75}$ Viz The Code of Conduct on Defence Procurement, European Defence Agency, 21. listopadu 2005.

${ }^{76}$ Elektronický věstník průmyslových zakázek je přístupný na URL: <http://www.eda.europa.eu/ebbweb>. 
${ }^{77}$ Viz The Code of Best Practice in the Supply Chain, European Defence Agency, 15. června 2006. Souhrnné informace EDA k problematice elektronického věstníku průmyslových zakázek jsou k dispozici na URL: $<\mathrm{http}: / /$ www.eda.europa.eu/genericitem.aspx?Area=Organisation\&ID=153>.

${ }^{78}$ Viz The Code of Conduct on Offsets, European Defence Agency, Steering Board Decision No. 2008/31, 24. ř́ijna 2008. V ČR jsou offsety neboli programy průmyslové spolupráce spojeny se zakázkami strategického charakteru nad 500 mil. Kč (u subdodávek nad 250 mil. Kč). Usnesení vlády České republiky ze dne 5. ledna 2005 č. 9 o Zásadách realizace programů průmyslové spolupráce dělí projekty průmyslové spolupráce (offsety) na př́mé, tzn. projekty zaměřené na přímou účast českých podnikatelských subjektů na výrobě předmětu veřejné zakázky (minimálně $20 \%$ hodnoty nákupní ceny předmětu veřejné zakázky), a nepř́mé, tj. všechny další projekty průmyslové spolupráce. Hodnota programu průmyslové spolupráce musí činit minimálně $100 \%$ celkové kontraktační ceny a doba plnění programu nesmí překročit dobu 10 let.

${ }^{79} \mathrm{Viz}$ The Code of Conduct on Offsets.

${ }^{80}$ Viz Key Industrial Capabilities: Future Air Systems, European Defence Agency, EDA Note for the Steering Board No. 2009/39, 9. října 2009.

81 Viz Key Industrial Capabilities: Ammunition Sector, European Defence Agency, Steering Board Conclusions, 9. října 2009.

${ }^{82}$ Viz Guidelines for Facilitating SME's Access to the Defence Market, European Defence Agency, Steering Board Decision No. 2009/37, 9. ř́ijna 2009.

${ }^{83}$ Viz ibid.

${ }^{84}$ Viz Capability Development Plan (CDP) Update, European Defence Agency, EDA Note for the Steering Board No. 2010/12, 25. března 2010. K vyhodnocení operací v rámci CSDP viz e.g. DEVAUX, Antoine, L'Union européenne et ses opérations militaires: perceptions et réalités, s. 105-114.

${ }^{85}$ Viz European Framework Cooperation - Launching EDA Contributions, European Defence Agency, EDA Draft Note for the Steering Board No. 2010/24 (Draft for Discussion at PrepCom on 16 April 2010), 31. března 2010.

${ }^{86} \mathrm{Viz}$ The Code of Conduct on Offsets.

${ }^{87}$ Viz Directive 2009/43/EC of the European Parliament and of the Council of 6 May 2009 Simplifying Terms and Conditions of Transfer sof Defence-related Products within the Community, Official Journal of the European Union, L 146/1, 10. června 2009.

88 Viz Directive 2009/81/EC of the European Parliament and of the Council of 13 July 2009 on the Coordination of Procedures for the Award of Certain Works Contracts, Supply Contracts and Service Contracts by Contracting Authorities or Entities in the Fields of Defence and Security, and Amending Directive 2004/17/EC, Official Journal of the European Union, L 216/76, 20. července 2009.

${ }^{89}$ Viz Treaty of Lisbon Amending the Treaty of the European Union and the Treaty Establishing the European Community, článek 45, odst. 2.

${ }^{90}$ Text Lisabonské smlouvy v otázkách týkajících se CSDP, tj. včetně EDA, kopíruje text Smlouvy o ústavě pro Evropu.

\section{LITERATURA}

\section{Prameny}

[1] The Approval of a European Defence Research and Technology Strategy. European Defence Agency, Steering Board Decision No. 2008/34, 10. listopadu 2008.

[2] Biological Equipment Development and Enhancement Programme - Preparation Phase BIO EDEP. European Defence Agency, Steering Board Decision No. 2009/21, 18. května 2009.

[3] Capability Development Plan (CDP) Update. European Defence Agency, EDA Note for the Steering Board No. 2010/12, 25. března 2010.

[4] The Code of Best Practice in the Supply Chain. European Defence Agency, 15. června 2006.

[5] The Code of Conduct on Defence Procurement. European Defence Agency, 21. listopadu 2005. 
[6] The Code of Conduct on Offsets. European Defence Agency, Steering Board Decision No. 2008/31, 24. ř́jna 2008.

[7] Collective Benchmarks. European Defence Agency, EDA Document No. 2007/13, 19. listopadu 2007.

[8] Defence Ministers Launch European Helicopter Training. European Defence Agency, Press Release, 17. listopadu 2009.

[9] Defence R\&T Joint Investment Programme on Force Protection. European Defence Agency, Steering Board Decision No. 2006/33, 13. listopadu 2006.

[10] Defence Test \& Evaluation Base Conceptual Guide. European Defence Agency, Steering Board Decision No. 2008/29, 15. ř́jina 2008.

[11] Directive 2009/43/EC of the European Parliament and of the Council of 6 May 2009 Simplifying Terms and Conditions of Transfer sof Defence-related Products within the Community. Official Journal of the European Union, L 146/1, 10. června 2009.

[12] Directive 2009/81/EC of the European Parliament and of the Council of 13 July 2009 on the Coordination of Procedures for the Award of Certain Works Contracts, Supply Contracts and Service Contracts by Contracting Authorities or Entities in the Fields of Defence and Security, and Amending Directive 2004/17/EC. Official Journal of the European Union, L 216/76, 20. července 2009.

[13] EDA Annual Report on R\&T Activities - 2009. European Defence Agency, 17. března 2010.

[14] Establishment of the European Third Party Logistic Support (TPLS) Platform. European Defence Agency, Steering Board Decision No. 2009/14, 2. dubna 2009.

[15] EU Third Party Logistic Support Platform Officially Launched. European Defence Agency, Press Release, 1. července 2009.

[16] European Air Transport Fleet. EDA Note for the Steering Board No. 2009/62, European Defence Agency, 6. listopadu 2009.

[17] European Armaments Co-operation Strategy, European Defence Agency, 13. února 2009.

[18] A European Armaments Co-operation Strategy. European Defence Agency, Steering Board Decision No. 2008/32, 15. ř́ijna 2008.

[19] A European Defence Research and Technology Strategy. European Defence Agency, 13. února 2009.

[20] European Framework Cooperation - Launching EDA Contributions. European Defence Agency, EDA Draft Note for the Steering Board No. 2010/24 (Draft for Discussion at PrepCom on 16 April 2010), 31. března 2010.

[21] European Helicopter Training Programme (HTP) Concept. European Defence Agency, EDA Document No. 2009/35, 17. listopadu 2010.

[22] European Satellite Communication Procurement Cell (ESCPC). European Defence Agency, Steering Board Decision No. 2009/34, 15. ř́jna 2009.

[23] European Secured Software Defined Radio Referential (ESSOR). European Defence Agency, Communication No. 07/09, 24. ledna 2007, a Communication No. 06/24, 9. března 2007.

[24] Framework Arrangement for Security of Supply Between Subscribing Member States (sMS) in Circumstance of Operational Urgency. European Defence Agency, Steering Board Decision No. 2006/17, 20. zář́i 2006.

[25] Future Trends from the Capability Development Plan. European Defence Agency, 21. řínna 2009. 
[26] Future Unmanned Aerial Systems (FUAS). European Defence Agency, Steering Board Decision No. 2008/36, 10. listopadu 2008.

[27] Guide to Conduct of Preparation Phase. European Defence Agency, Steering Board Decision No. 2008/30, 15. ř́ína 2008.

[28] Guide to the Conduct of a Programme Preparation Phase (Draft 4). European Defence Agency, URL: <http://www.eda.europa..eu/genericitem.aspx?area= Organisation\&id=108>.

[29] Guidelines for Facilitating SME's Access to the Defence Market. European Defence Agency, Steering Board Decision No. 2009/37, 9. října 2009.

[30] Identified Collaborative Opportunities in the CDP Collaborative Database. European Defence Agency, EDA Document No. 2008/28, 8. července 2008.

[31] Innovative Concepts and Emerging Technologies (ICET). European Defence Agency, Steering Board Decision No. 2008/17, 26. května 2008.

[32] An Initial Long-Term Vision for European Defence Capability and Capacity Needs, European Defence Agency. 3. ř́ijna 2006.

[33] Interim Synthetic Helicopter Tactics Course. European Defence Agency, Steering Board Decision No. 2009/40, 27. ř́ína 2009.

[34] Key Industrial Capabilities: Ammunition Sector. European Defence Agency, Steering Board Conclusions, 9. ř́íjna 2009.

[35] Key Industrial Capabilities: Future Air Systems. European Defence Agency, EDA Note for the Steering Board No. 2009/39, 9. října 2009.

[36] Maritime Mine Counter-Measures. European Defence Agency, Steering Board Decision, No. 2008/35, 10. listopadu 2008.

[37] Midair Collision Avoidance System for UAV/UCAV - (MIDCAS). European Defence Agency, Steering Board Decision, No. 2008/19, 17. června 2008.

[38] Multinational Space-Based Imaging System. European Defence Agency, Steering Board Decision No. 2009/01, 3. března 2009.

[39] Proposed Conclusions from the Capability Development Plan. European Defence Agency, EDA Document No. 2008/26, 8. července 2008.

[40] Road Map on an EU-wide Forum for MAWA. European Defence Agency, Steering Board Decision No. 2008/39.

[41] A Secure Europe in a Better World, European Security Strategy. 12. prosince 2003.

[42] Selection of Proposals to Be Contracted and on the Negotiation Mandate for the 3rd Call for Proposals of the JIP-FP. European Defence Agency, JIP-FP Management Committee Decision No. 2008/19, 16. prosince 2008.

[43] Společná akce Rady 2004/551/SZBP ze dne 12. července 2004 o zř́zení Evropské obranné agentury. Úřední věstník Evropské unie, L 245/17, 17. července 2004.

[44] A Strategy for the European Defence Technological and Industrial Base. European Defence Agency, Steering Board Decision No. 2007/11, 14. května 2007.

[45] Treaty of Lisbon Amending the Treaty of the European Union and the Treaty Establishing the European Community. Official Journal of the European Union, C 306, 17. prosince 2007.

[46] Usnesení vlády České republiky ze dne 5. ledna 2005 č. 9 o Zásadách realizace programů průmyslové spolupráce. 


\section{Články}

[47] BRÉANT, Christian. Five Years of EDA Collaborative Defence R\&T. EDA Bulletin. February 2010, č. 13, s. 8-9.

[48] DEVAUX, Antoine. L'Union européenne et ses opérations militaires: perceptions et réalités. Défense nationale et sécurité collective. 2009, roč. 65, č. 11, s. 105-114. ISSN 1950-3253.

[49] European Defence Agency. EDA Achievements since 2004. EDA Bulletin. February 2010, č. 13, s. 4-5.

[50] JORDAN, Graham; WILLIAMS, Tim. Hope Deferred? The European Defence Agency after Three Years. RUSI. 2007, roč. 152, č. 3, s. 66-70. ISSN 0307-1847.

[51] KOLÍN, Vilém. Evropská obranná agentura po třech letech. Obrana a strategie. 2007, roč. 7, č. 2, s. 73-85. ISSN 1214-6463.

[52] MEIRIÑO, Arturo Alfonso. El nuevo marco Europeo para el mercado de la Defensa. Revista Española de Defensa. 2009, roč. 22, č. 255, s. 44-49. ISSN 1131-5172.

[53] SCHMITT, Andreas. EDA und OCCAR - Starke Partner für Europas Streitkräfte. Europäische Sicherheit. Juli 2009, s. 18-22.

[54] WEIS, Alexander. Project, Project, Project. EDA Bulletin. February 2009, č. 10, s. 1-3. 